\title{
44. ON THE JURASSIC ATLANTIC OCEAN AND A SYNTHESIS OF RESULTS OF DEEP SEA DRILLING PROJECT LEG 76
}

\author{
Felix M. Gradstein, Geological Survey of Canada, Bedford Institute of Oceanography, Dartmouth, Nova Scotia, \\ Canada, B2Y 4A2 \\ and \\ Robert E. Sheridan, Department of Geology, University of Delaware, Newark, Delaware
}

\section{INTRODUCTION}

In this Initial Report of the Deep Sea Drilling Project, detailed studies of Sites 533 (gas hydrates) on the Blake Outer Ridge and 534 (oldest ocean history) in the Blake-Bahama Basin have provided answers to many geological and geophysical questions posed over the decade that deep drilling has been undertaken in this part of the western North Atlantic. The history of drilling and a historical review of key scientific accomplishments have been presented in the Introduction (Gradstein and Sheridan, this volume). In this final chapter we review highlights of new geological, geophysical and paleoceanographic interpretations presented in this volume, and offer a critical review of this information. We conclude with a listing of some outstanding problems and recommendations for future research, including data collection.

The following subjects are addressed: (1) summary of Sites 533 and 534-litho-, bio-, magneto-, and seismostratigraphic interpretations (Figs. 1-3); (2) the quest for the oldest oceanic sediments (Fig. 4); (3) the age of basement at Site 534; (4) the Jurassic time scale and a stratigraphic synthesis chart for the western North Atlantic (Figs. 5, 6); (5) implications for early spreading rates and the age of the Blake Spur Marine Magnetic Anomaly (BSMA) (Fig. 7). (6) implication of the age of the Blake Spur Marine Magnetic Anomaly (BSMA) to the North American margin; (7) pulsation tectonics; (8) $160 \mathrm{~m}$.y. of subsidence and sedimentation and the controversy around the Cenomanian-Miocene gap in the ocean record (Figs. 9, 10); (8) sediment accumulation at Site $\mathbf{3 9 1}$ and at Site 534, as well as Late Cretaceous to Paleogene deposition and erosion, or nondeposition in the Blake-Bahama Basin; (9) Jurassic paleogeography and paleocirculation (Fig. 11a-c); (10) black shales depositional models and hydrocarbon source potential (Fig. 12); (11) seismic stratigraphy of the Blake-Bahama Basin; (12) origin of the mass flow deposits of the Miocene Great Abaco Member and the Eleuthera Fan complex; (13) gas hydrates on the Blake Outer Ridge; (14) heat flow in the Blake-Bahama Basin; (15) contourite formation of the Blake Outer Ridge; and (16) recommendations for future drilling and research.

\footnotetext{
${ }^{1}$ Sheridan, R. E., Gradstein, F. M., et al., Init. Repts, DSDP, 76: Washington (U.S. Govt. Printing Office)
}

\section{SITES 533 AND 534-SUMMARY OF ACCOMPLISHMENTS}

Hydraulic piston coring, rotary coring, and deployment of the heat flow-pore water sample and pressure core (PCB) barrel to a depth of $399.5 \mathrm{~m}$ at Site 533 (Figs. 1, 2) on the Blake Outer Ridge has given us:

(1) A stratigraphically continuous record of middle Pliocene-Holocene gray green mudstones used by Moullade (this volume) and Blanc-Vernet (this volume) to evaluate sedimentation rate, climatic fluctuations, and deep circulation.

(2) A temperature gradient of $5.1^{\circ} \mathrm{C} / 100 \mathrm{~m}$ near the seafloor to $3.6^{\circ} \mathrm{C} / 100 \mathrm{~m}$ at the bottom of the hole, which agrees with the prediction that the strong bottom simulating reflector at $0.60 \mathrm{~s}$ is the result of gas hydrate inversion.

(3) Direct observation of a few thin beds $(3.5 \mathrm{~cm})$ of gas hydrate at $240 \mathrm{~m}$ sub-bottom, confirming that gas hydrates exist in the Blake Outer Ridge sediments, but

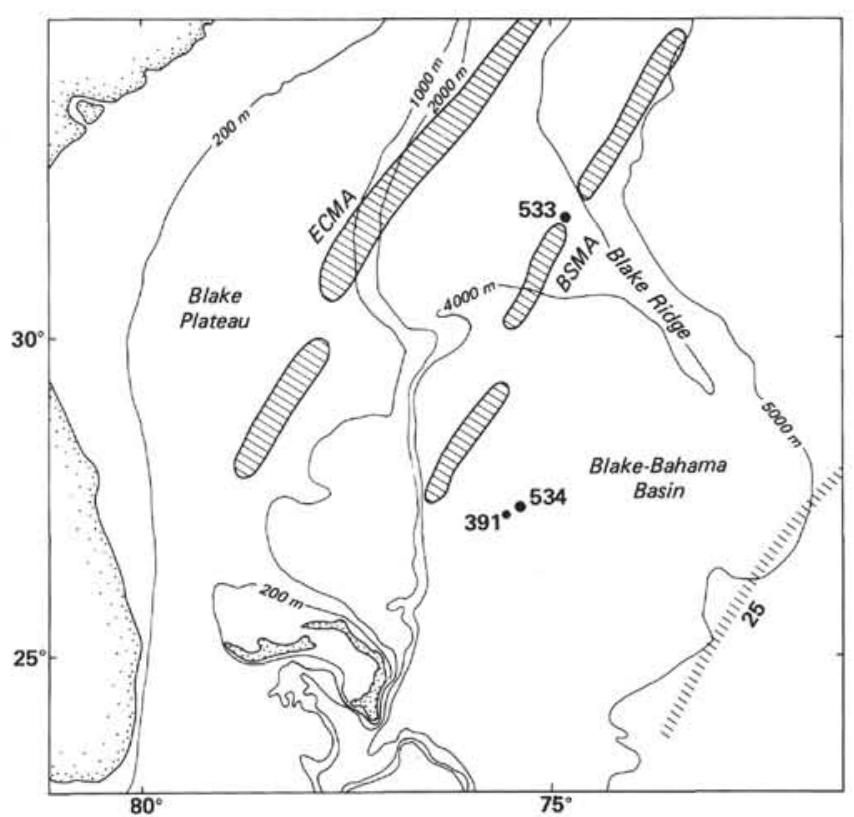

Figure 1. Location of Site 533, on the Blake Ridge, and Sites 534 and 391 , in the Jurassic Marine Magnetic Quiet Zone relative to the marine magnetic Anomalies M-25 and the Blake Spur. (BSMA $=$ Blake Spur Magnetic Anomaly and ECMA = East Coast Magnetic Anomaly.) 
possibly only in small lenses. There is at present no satisfactory chemical model with which to relate the low methane generation in Site 533 to the gas hydrate presence, which requires higher $\mathrm{CH}_{4}$ concentrations than were observed (Claypool and Threlkeld, this volume). There is uncertainty about how the amounts of gas hydrates present in the hydrated sediments produce the acoustic properties of slightly higher seismic velocities and apparent transparency.

(4) Indirect evidence of the presence of gas hydrate that comes from PCB retrievals in which the pressure decline survey shows the sawtooth pattern characteristic of hydrate decomposition (Kvenvolden and Barnard, this volume; Brooks et al., this volume).

(5) Molecular and isotopic ratios of gas samples from the hydrates and hydrated sediments that indicate a local biogenic source for the methane gas, the predominant gas constituent. There appears no migration of gas from deeper horizons, derived from thermal maturation.

(6) A lack of obvious current-derived visual structures in the calcareous clay and mud makes it difficult to identify the Blake Outer Ridge sediments as contourites (Site 533 report, this volume).

Figure 2 (also in the Site 533 report) shows the composite core, biostratigraphic, and geochemical and physical properties record at Site 533 .

The composite stratigraphy of Site 534 is shown in Figure 3. This site, in the Blake-Bahama Basin, was continuously cored from 545 to $1666 \mathrm{~m}$ sub-bottom $(56 \%$ recovery). The sediment record spans $160 \mathrm{~m}$.y. of ocean history and cored the oldest (middle Callovian) oceanic sediments yet recovered. The Site 534 report and a large number of specialty chapters in this volume deal with this excellent geological and geophysical record and include, among other data:

(1) A Miocene record of extensive debris flow, grain flow, and turbidite deposition that can be traced to part of a deep-sea fan complex, funneling out of the Bahama Canyons.

(2) Evidence for hiatuses and nondeposition in the Late Cretaceous as well as in the Paleogene. Slow deposition coupled with nondeposition, rather than rapid deposition followed by drastic erosion in a single Oligocene event, may have caused the 60-m.y. gap in the record.

(3) A complete section of Cretaceous black shale that has been more closely sampled and better dated than in any previous studies.

(4) Documentation of a more shaly upper section of the Neocomian Blake-Bahama Formation revealing a facies change with respect to nearby Site 391 . This facies change, related to increased influx of terrigenous components toward land, occurs all along the North American margin.

(5) Dating of an excellent Middle and Upper Jurassic pelagic record of variegated shales, radiolarian silts, turbiditic limestones, and reddish clays. The multiple biostratigraphic and paleoecologic studies (see specialty chapters in this volume and Site 534 report) greatly increase our insight into zonal correlation problems concerning stage boundaries of the Callovian, Oxfordian,
Kimmeridgian, and Tithonian, as recognized in a pelagic biofacies. It also has significantly increased our understanding of biota distribution and oceanic paleoenvironment in the Jurassic.

(6) Continuous coring of Jurassic strata that has led to recovery of basal sediments, classified here as of preCat Gap Formation character and age. It should be pointed out here that Ogg et al., (this volume) have proposed a change in the definition of the Upper Jurassic Cat Gap Formation as observed at Site 534. The new definition (Fig. 3) now includes the dark variegated claystones and limestones of Subunits $7 \mathrm{a}$ and $\mathrm{b}$ (Cores 119-111) below the micritic-bioclastic limestone and greenish gray clays in Subunit $6 \mathrm{~b}$ (Cores 110-104) and the variegated (reddish) claystones of Subunit $6 \mathrm{a}$ in the Cat Gap Formation. This expanded section, which has only been observed at Site 534, now places all of the Jurassic sediments above seismic Horizon D in the Cat Gap Formation. The silty radiolarian-rich claystones and pelletal limestones below Core 119 and older than seismic Horizon D make up the basal, unnamed oceanic lithostratigraphic unit. This new definition makes the turbiditic limestones forming Horizon D an integral part of the Cat Gap Formation. We are somewhat hesitant to accept redefinition of oceanic formations based on single site criteria, without proof of mappability, but we do show the new subdivision in Figure 3. Future drilling in the western North Atlantic will have to substantiate this lithologic record on a regional scale.

(7) Better dating of the Jurassic-Neocomian geomagnetic record (J. Ogg, this volume) between M-24 and M-26. Seismic Horizon D has been shown to be early Oxfordian (approximately equivalent in age to Anomaly M-27), and Horizon $\mathrm{C}$ has been confirmed to occur at the Jurassic/Cretaceous boundary (M-18-M-19) (Fig. 3).

(8) Recovery of Callovian shales on ocean crust-type basalt (Logothetis, this volume). These shales represent the oldest recovered sediments used to document oceanic spreading.

(9) Recovery of the first samples of Jurassic Magnetic Quiet Zone oceanic basaltic basement. Steiner (this volume) finds this Quiet Zone crust to be of uniform magnetic susceptibility and constant polarity, which leads to the assumption that the Jurassic Magnetic Quiet Zone is truly quiet.

\section{THE QUEST FOR THE OLDEST OCEANIC SEDIMENTS}

The principal objective of Site 534, Hole 534A was to extend significantly our knowledge of the Jurassic Atlantic Ocean beyond what was known from earlier drilling during Legs 1,11 , and 44 in the western North Atlantic and Legs 41 and 50 in the eastern half, off northwest Africa. Prior to 1980 no ocean site had penetrated rocks much below seismic Horizon C, (i.e., older than the Late Jurassic) or closer to the continental margin than M-25. In a nutshell this history is depicted in Figure 4. Sites 100 and 105 (Leg 11, Hollister, Ewing, et al., 1972) and Site 367 (Leg 41, Lancelot, Seibold, et al., 1978 ) were drilled within the area of Anomaly M-25, or landward of the edge of the so-called Jurassic Magnetic 
Quiet Zone (JQZ), which is devoid of high-amplitude magnetic anomalies. The sites bottomed in reddish calcareous shale to gray, shaly limestone of the OxfordianKimmeridgian. Both Site 391 (Leg 44, Benson, Sheridan, et al., 1978), which is 15 nautical miles ( $22 \mathrm{~km})$ southwest of Site 534, and Site 416 (Leg 50, Lancelot, Winterer et al., 1980) drilled in the JQZ region, but failed to reach basement or extend far into Jurassic strata. In the Pacific, Site 462 (Leg 61) failed to reach JQZ-age rocks, but a new attempt was made to do so in 1982 during Leg 89 of the Deep Sea Drilling Project. In the Indian Ocean, off the western Australian passive margin, Site 261 (Leg 27), on about M-22, encountered Oxfordian-Kimmeridgian shaly sediments on basement.

Site 534 , on the flank of a small basement high in a negative lineation of weak magnetic amplitude in the JQZ (Fig. 1) called M-28 (Bryan et al., 1980), bottomed at $1666 \mathrm{~m}$ in tholeiitic pillow basalt, typical elsewhere of oceanic basement. The basalt includes centimeter-thin, reddish shale intercalations, in microfacies and lithology similar to the sediment immediately overlying the basalt. Microfossil recovery includes pelagic lamellibranchs and some long-ranging benthic foraminifers. This shale testifies to the lack of a significant time interval between deposition of pillow lava flows on the Ridge and the overlying sediments. Also the basal shale is slightly altered hydrothermally (Chamley, this volume), the result of higher heat flow during initial cooling of the crust.

Using radiolarian, dinoflagellate, and nannofossil biostratigraphy, the basal sediments in Hole 534A were unambiguously dated as middle (-late) Callovian.

\section{AGE OF BASEMENT AT SITE 534}

One of the most significant results of drilling at Site 534 was the dating of the oceanic basement at the Site. To accept this dating as valid, we have to consider several factors that bear on the question. From the very beginning of the Deep Sea Drilling Project, there have been challenges to the assertion that the deep-sea drilling results truly date the basement. The most important challenge was the charge that the basalt recovered at the bottom of the holes was not basement but some sill that has intruded the sediments. Critics complained that drilling had only continued a few meters farther, the oldest sediments at the site would have been recovered. As it turns out, this argument is countered at many sites where the extrusive nature of the pillow basalts recovered is well documented. Site 534 is one such site. According to the petrologists of the Shipboard Party (Site 534 report, this volume) and Logothetis (this volume), the pillow margins are clearly evident from the contact relationships between the basalt and the thin $(5-\mathrm{cm})$ layers of slightly altered, intercalated sediments. The effects of quick chilling by seawater of the rinds of the pillows, the thermal cracking, and the size of the pillows are all rather typical of oceanic basalts of layer 2 . These factors rule out the intrusive nature of the basalt.

Another argument is that the basalt flows encountered are interstratified with thick layers of even older sediments, and thus the true base of the sequence zould not have been drilled. This point cannot be countered with the drilling data available at Site 534 , because only $30 \mathrm{~m}$ of basalt were cored. The decision to terminate drilling was made in order to log the hole as early as possible and finish Leg 76, which had already been extended at the expense of Leg 77. Consequently, the possibility of a pillow basalt flow sequence only $30 \mathrm{~m}$ thick above older sediments cannot be refuted. However, the seismic reflection profiles at the Site (Site 534 report, this volume; Sheridan et al., this volume) reveal a typical hyperbolic reflection pattern commonly recorded for oceanic basement. No indication of interstratified basalt flows and sediments is suggested, either in the sediments above acoustic basement or as sub-basement reflectors. There are documented cases in which basalt flows interbedded with sediments have been detected on seismic reflection profiles, and an obvious interlayering is resolvable. In these examples the basalt layers have strong seismic amplitudes and a small-scale hummocky upper surface, and are relatively planar reflectors that do not persist over a wide area. None of these characteristics are seen at Site 534. It appears that the basalt layer encountered at the bottom of Hole 534A is truly the top of seismic layer 2 , oceanic basement. In any case, the Site 534 basalt layer is not different in appearance and petrography from oceanic basement, and should be considered no less valid as documented basement than that at many other DSDP sites.

Given the well-established geologic age of the sediments just above basement as no older than middle Callovian (Site 534 report, this volume), the physical evidence of the penecontemporaneous deposition of these sediments with the uppermost basalt layers supports the conclusion that the age of the sediments is the same as the age of the basalt. The evidence for the continuum of deposition between the basalt and the sediments, without a major hiatus, is seen in the cores that were cut continuously across this contact. The contact shows up within a single core section. Chamley et al. (this volume) report that the claystones directly in contact with the basalt have been altered by the thermal affects of the cooling lava, so sediment deposition closely followed lava emplacement.

Another argument has been suggested that might cast doubt on the age of anomaly M-28. This is the possibility that the basalt cored was an off-axis event, perhaps along a fracture zone, which extruded several million years after the true, older crust was formed at the site. Although we have no data to contradict this suggestion, the probability of such an anomalous event has to be considered in light of past drilling results. Lowrie et al. (1980) have dated many Tertiary and Cretaceous magnetic reversals in the Tethyan stratigraphic sections. When comparing their data with the ages of sediments on basalt in the DSDP sites on many equivalent seafloor anomalies, the DSDP ages are generally very agreeable (Channell et al., in press). Seismic mapping of the Jurassic Quiet Zone shows little evidence of extensive seamounts that might have been produced by late-stage, younger intraplate volcanism affecting this area of the western North Atlantic. We can only assume that the basalt at Site $\mathbf{5 3 4}$ is typical of that forming oceanic layer 2 


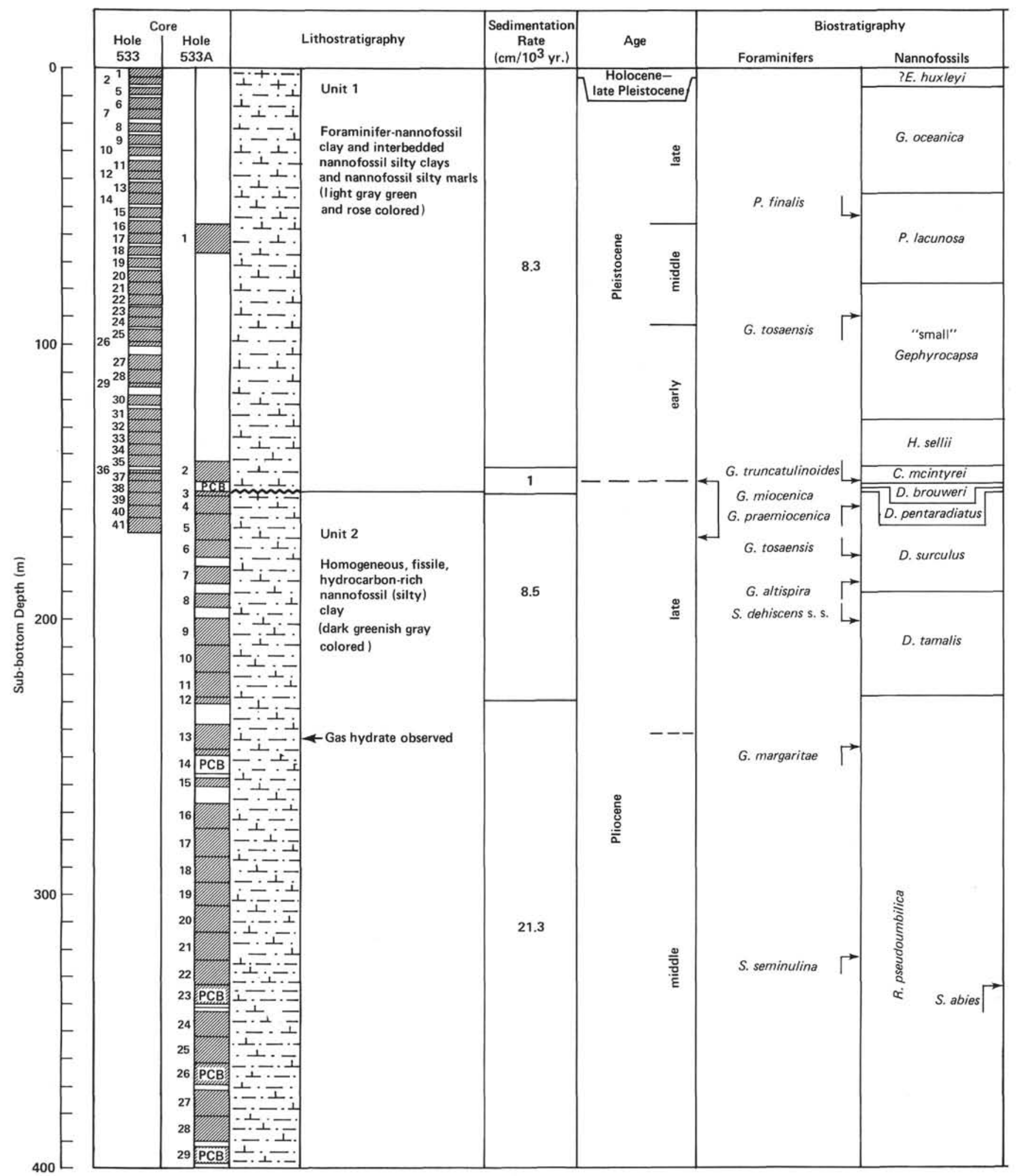

Figure 2. Stratigraphic summary of Site 533, DSDP Leg 76, Blake Outer Ridge, western North Atlantic Ocean.

created at the rift axis. Nothing in the mineralogy of these typical tholeiitic basalts suggests otherwise (Logothetis, this volume).

The near fracture zone position of Site 534 does present a slight controversy. The engineering drill string limit of the Glomar Challenger $(6800 \mathrm{~m})$ required that the site be on the flank of a basement high where basement was mapped at a depth of $8.0 \mathrm{~s}$ two-way traveltime. A site near the fracture zone would have been preferable, because in this basement trough ( $8.2 \mathrm{~s}$ depth) the $\mathrm{D}$ 


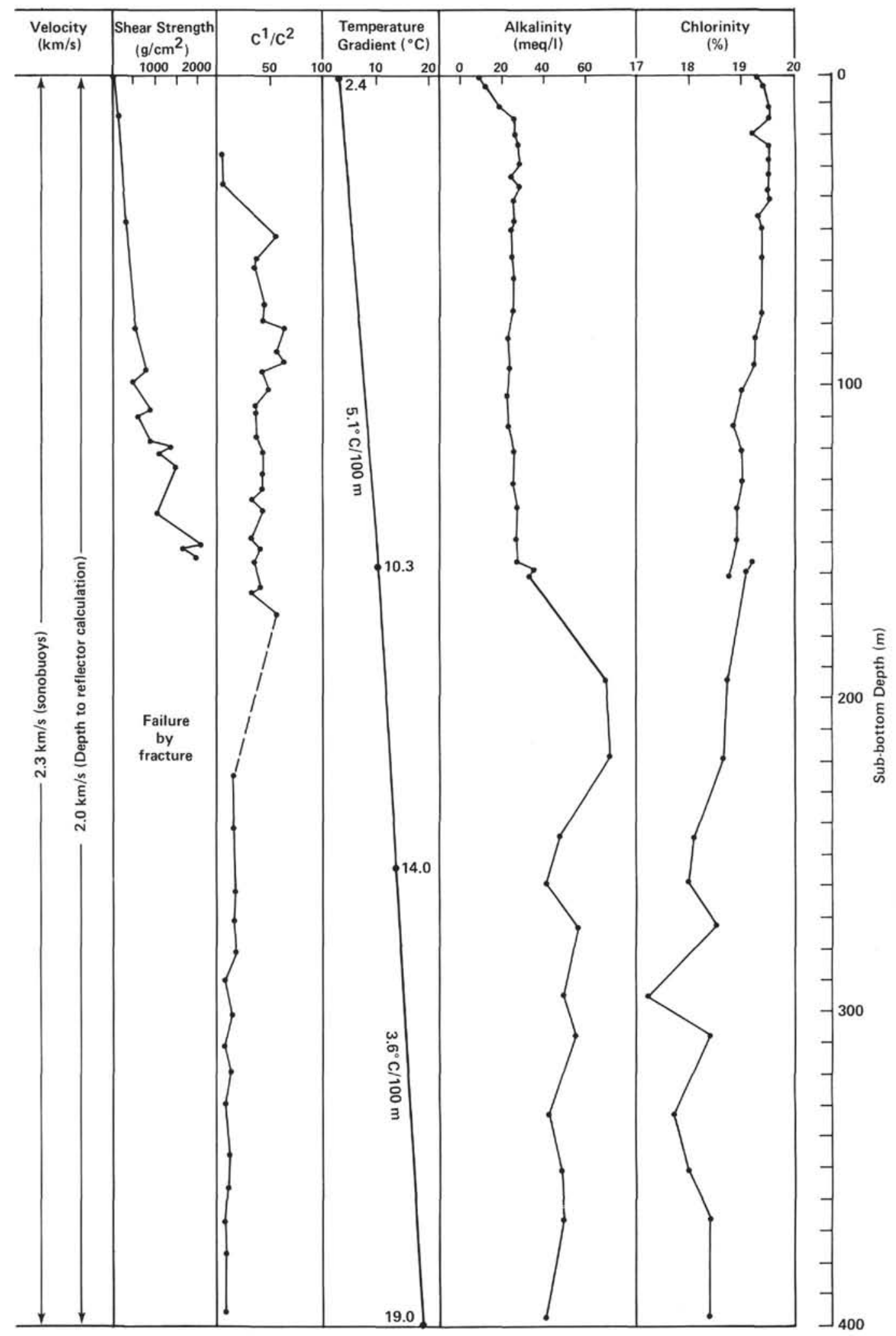

Figure 2. (Continued).

to basement sediment interval (Sheridan et al., this volume) was more thickly developed, and it was clear that seismic Horizon D could be penetrated and identified. Consequently, there are about $200 \mathrm{~m}$ more sediments below the $\mathrm{D}$ to basement interval in the center of the fracture zone trough than on the flank where Site 534 was located, which leads to the argument that even older sediments would have been recovered from the center of the trough if the drilling capability existed to reach them. 


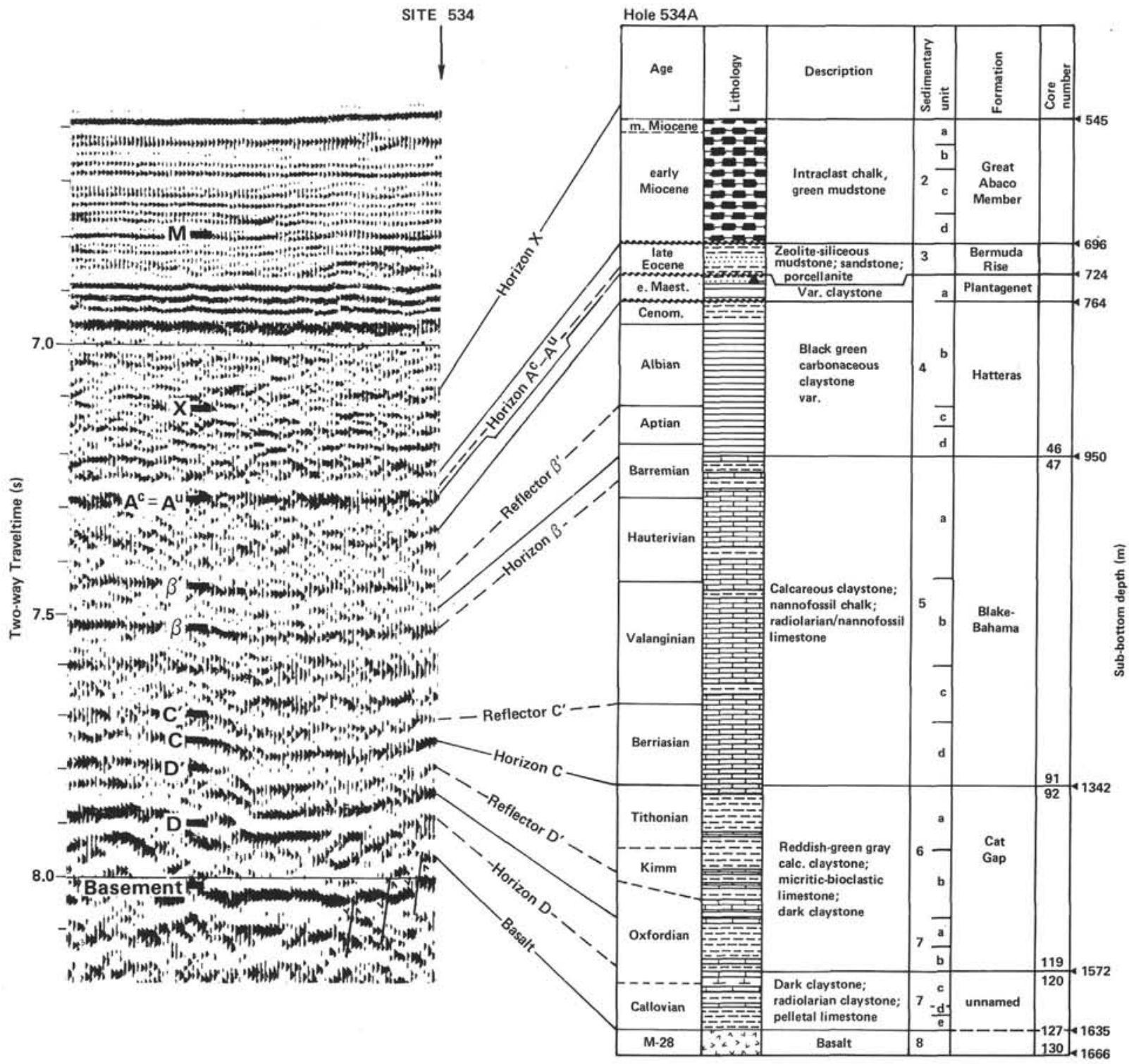

Figure 3. Stratigraphic summary of Site 534, DSDP Leg 76, Blake-Bahama Basin, western North Atlantic Ocean.

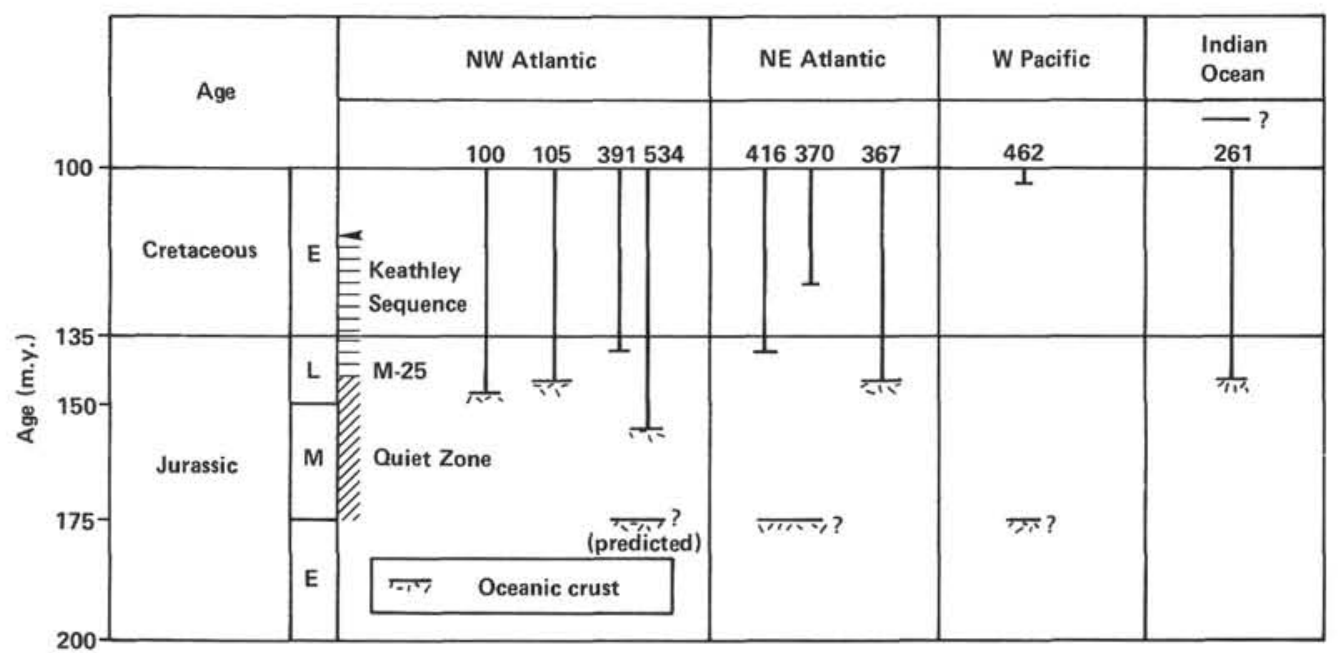

Figure 4. The quest for the oldest oceanic sediments from 1972 to $1980-$ DSDP legs aimed at resolving early ocean history. 
Our only reply to such an argument is that the earliest sediments in contact with the basalt are of a pelagic and hemipelagic type that were draped over the basement, possibly by deep-sea currents, during a time when the Site was above the sill depth produced by the Blake Spur Ridge (Sheridan et al., this volume) and at a time when basin-leveling turbidites could not reach it. If this interpretation is correct, and if the draped deposits are preferentially mounded on the north side of the fracture zone trough, then conceivably the sediments in the center of the trough and on the flank are of essentially the same age. In modern fracture zone environments where the transparent drape sediments and contourites are found (Sheridan et al., this volume) the relief in the sediments of the same age can be as much as 100 to $200 \mathrm{~m}$.

In our opinion, considering all these arguments, the age of the basement and of the crust at anomaly M-28 is determined by the age of the basal sediments drilled at Site 534-middle Callovian or approximately $153 \mathrm{Ma}$.

\section{THE JURASSIC TIME SCALE AND A STRATI- GRAPHIC SYNTHESIS CHART FOR THE WESTERN ATLANTIC}

Organization of many paleontological and geological interpretations in a linear, numerical fashion, and calibrated to a geochronologic radiometric time scale serves many purposes. The approach provides rates of change of biological, geological, and oceanographic processes and helps in clarifying trends. Two common approaches involving expression in a numerical scale are used in this volume; the calculation of early spreading rate and the subsidence and sedimentation rates at Sites 533 and 534 . Because both methods have been used to extrapolate back to the time of early opening (Vogt and Einwich, 1979; Bryan et al., 1980) of the Atlantic Ocean, it might be instructive to analyze briefly the time scale itself. In the process we propose an update of a commonly used Jurassic scale and present a chart documenting key geological, paleontological, and paleoceanographic events during the long history of the western North Atlantic.

In their calculation of the Atlantic early spreading rate Vogt and Einwich (1979) used the time scale proposed by van Hinte $(1976 \mathrm{a}, \mathrm{b})$. This scale uses a multiple approach to numerical calibration of Jurassic stages, rather than the arbitrary "equal duration of stages" model and a few key radiometric dates that are used as a working hypothesis in the Geological Society of London (1964) scale.

Modern absolute time scales can make use of several approaches: (1) best fit of radiometric ages plotted versus chronostratigraphic dates of the rocks in question and adjusted to the standard set of decay constants and isotopic abundances (Armstrong 1978; Webb 1981); (2) linear scaling of stages using the concept of equal duration of the biozones that characterize each stage (in this way stage boundaries can be interpolated from few and far-between numerical ages); (3) extrapolation to find numerical ages of stage boundaries, using constancy of average sedimentation rates in well-dated sections; (4) interpolation and calibration to find the age of geomagnetic and biostratigraphic-chronostratigraphic "events" and boundaries, using constancy of seafloor spreading to obtain a linear scale between marine magnetic anomalies; these anomalies can also be recognized as reversals in sedimentary sections.

The Jurassic scale of van Hinte (1976b) makes use of these approaches. In contrast, Armstrong (1978), in his pre-Cenozoic date file, only used interpolations between radiometric dates that were strictly based on accepted decay constants of isotopic systems. For the Jurassic, few good dates are available and the Oxfordian-Callovian and Toarcian-Aalenian have no absolute dates to support this interpolation. Armstrong (1978) only uses maximum age data of a series, that is, the oldest value of age assignments to compensate for daughter-product loss. The Armstrong (1978) scale for the Jurassic is shown in Figure 7, together with an updated version of the van Hinte (1976b) scale. It is obvious that there are substantial discrepancies in numerical age, the first scale being older by 5 to $10 \mathrm{~m} . \mathrm{y}$. and having different stage duration proportions. The preferred (multiple) scale, updated from van Hinte (1976b), has been derived as follows.

The Triassic/Jurassic boundary is best placed at about $200 \mathrm{Ma}$ rather than at $192 \mathrm{Ma}$. This value is a reasonable midpoint of about 15 individual $\mathrm{K} / \mathrm{Ar}$ and $\mathrm{Rb} / \mathrm{Sr}$ dates, with a range of 215 to $185 \mathrm{Ma}$ (Webb, 1981). These older data come close to Webb's (1981) age of $205 \mathrm{Ma}$.

Next, we have used Hallam's (1975) rather than Arkell's (1956) standard ammonite zonation for the Hettangian to Bajocian (Fig. 5). If we retain $165 \mathrm{Ma}$ for the upper limit of the Bajocian and use 30 Hettangian-Bajocian standard zones, a zone averages $1.2 \times 10^{6} \mathrm{~m}$.y. long, and thus allows calculation of stage limits as shown. For the Bathonian through Tithonian, no time scale changes have been made, although the Bathonian may be too long. This is because the zonation may have been oversplit, leading to stacking of subzones and zones (G. Westermann, personal communication, 1982) here assumed to be of equal duration. The Tithonian lower boundary is based on the appearance of Gravesia, which leads to the short (French) Kimmeridgian, recognized by French workers.

The marine and sedimentary reversal scale has been calibrated as follows: The geomagnetic polarity time scale of M-28 to M-25 to M-0 was initially stretched between tie points, as discussed by J. Ogg and R. Sheridan in the Site 534 report. It was subsequently compared to and adjusted for stratigraphic assignments of sedimentary and ocean basement reversals in land sections and in DSDP Sites $166,387,307,105$, and 534. The M-0 date of early Aptian, or $\pm 114 \mathrm{Ma}$, is based on Lowrie et al., 1980. The Cretaceous Magnetic Quiet Zone is Albian through Santonian. Anomaly M-7-8, based on DSDP Site 166, has been argued by van Hinte (1976a) to be possibly $125 \pm 5 \mathrm{Ma}$, which is slightly older than favored by Channell et al. (in press), who use interpolations between other reversals. Unfortunately the range of biostratigraphic assignments at Site 166 is such (Hauterivian-Albian) that no firm conclusions are possible to verify Channell et al.'s interpolation. Anomaly M-16, based on Site 387, occurs at or below the Berriasian/ 
Valanginian boundary; M-17 is basal Berriasian in Ogg (1980) and Channell et al. (in press). If basement is Tithonian at DSDP Site $307, \mathrm{M}-21$ is 140 to $135 \mathrm{~m}$.y. old, if Tithonian-Berriasian, it is slightly younger. For M-24 and M-25 at Site 534 (Table 1), all reasoning presented suggests a position in or just below the Oxfordian/Kimmeridgian transition or near $143 \mathrm{Ma}$, an estimate also favored by Channell et al. (in press).

The small amplitude marine magnetic Anomaly 27, sensu Bryan et al. (1980), can be dated using the pinchout of seismic reflector D against basement of the M-27 signature. Drilling at Site 534 has shown D to be early-middle Oxfordian, and M-27 is placed in the early Oxfordian. As shown by Site 534 drilling, small amplitude Anomaly M-28 is likely early Callovian.

Finally, the distances were (again) measured for the mapped marine anomalies of M-0, M-7 to M-8, M-16, M-17, M-21, M-25, M-27, M-28, and the Blake Spur Anomaly (BSA) in the Blake-Bahama Basin. A spreading rate of $1.7 \mathrm{~cm} / \mathrm{yr}$. between M-0 to M-21 and of $3.1 \mathrm{~cm} / \mathrm{yr}$. between M-21 and M-28 and BSA provides a good linear fit of the data and establishes the age of the BSA at the Bathonian/Callovian boundary.

The Figure 5 chart (see back pocket) combines the geomagnetic scale, geological and paleontological (biostratigraphical) events or zonations used to reconstruct the history of the western North Atlantic Ocean and to some extent the margin also. Emphasis is on "stepping stones" during the Mesozoic. Choice of standard ammonite zonation for the Jurassic has been discussed earlier. There is good calibration between the Early Jurassic benthic foraminiferal ranges studied in the Grand Banks and Portuguese basins (Gradstein, 1977; Exton and Gradstein, in press) and the ammonite zones. There is no Early and early Middle Jurassic foraminiferal record known from the western Atlantic oceanic realm. Few taxa (indicated with an * in Fig. 5) are probably exclusive of neritic biofacies and many probably occurred in deep, oceanic sediments. Increasing provincialism since the Late Jurassic precludes recognition of many of the events in high latitudes, although along the western Atlantic strong Tethyan influences extended to the northern limit of the marine Jurassic and Early Cretaceous realm in the Newfoundland Basin.

The Jurassic planktonic foraminiferal record is well established on the Grand Banks and probably includes the first appearance of this group from an unknown ancestor. The Atlantic pelagic record of this group is sparse and confined to some specimens in Oxfordian strata (see the summary in Gradstein, this volume). The group was essentially confined to the epicontinental seas and ocean margins in the Jurassic and also in the Neocomian.

The Cretaceous planktonic foraminiferal zonation, as expressed in the LC (Lower Cretaceous) and UC (Upper Cretaceous) units adopted by van Hinte (1976a), is only applicable in part. First, there is the extensive Late Cretaceous hiatus in the bathyal and abyssal Atlantic realm; second, LC14, UC4, UC8, UC11, and UC13 are hard to recognize, if they are recognizable at all, in the Atlantic region. Cretaceous benthic foraminifer events largely follow studies by Moullade (1966), van Hinte (1976a), Ascoli (1977), Gradstein (1978, and unpublished data), and Drushtchitz and Gorbatschik (1978).

The Early and early Middle Jurassic palynological zonation developed by Bujak and Williams (1977) and S. Davies (personal communication, 1982) on the western Atlantic margin is in reasonable agreement with that using foraminifers. It has been compared to the ammonite succession shown. For the younger Jurassic and Cretaceous stratigraphic section the dinoflagellate biostratigraphy as developed by D. Habib for the pelagic realm is shown (Habib and Drugg, this volume). This biostratigraphy is explained by these authors in terms of ammonite zonations and stratotype coverage. The subdivision shown is reasonably in agreement with that of P. Roth et al., (this volume) and P. Roth (1978) using nannofossils, but only for parts of the section. There are calibration problems in the Oxfordian, Kimmeridgian, early Tithonian, Hauterivian, and Aptian. Some of these inaccuracies will be dealt with later. Jurassic nannofossil datums and their relation to ammonite zones as shown follows Roth et al. (this volume) and D. Watkins (personal communication, 1982).

The Late Cretaceous nannofossil zonation is that adopted from Tethyan standard zonations and used for the western Atlantic margin (Doeven et al., 1982 and Doeven, in press). The calpionellid zonation follows Remane (1978); the cephalopod (ammonites and aptychi) correlation scheme in the pelagic biofacies is that of Renz (this volume). The Tethyan radiolarian zonation applicable to the western Atlantic was developed by P. Baumgartner (this volume).

Following this introduction, a presentation is made on Late Jurassic stratigraphic inaccuracy in DSDP sites, with special reference to Site 534 (Table 1). The oldest foraminiferal assemblage in Hole 534A, which also occurs in other DSDP Sites, was found in Cores 102 through 96, that is, the co-occurrence of Lenticulina quenstedti and Epistomina aff. uhligi. This co-occurrence correlates directly to the basal Cores 50 through 52 in western Atlantic Hole 391C, to Cores 36 and 37 (two cores above basalt) in western Atlantic Site 105, and to Cores 35 through 37 (immediately above basalt) in eastern Atlantic Site 367 (Fig. 6).

At Site 534 the interval between Cores 96 and 102 contains magnetic reversals M-20 to M-24 (J. Ogg, this volume), which is consistent with the fact that at both Sites 105 and 367 , basaltic basement is aproximately M-25 or slightly older, and the overlying sediments should be of an age just post M-25. This also agrees with the lithostratigraphic correlations of $534,105,367$, and 391 which, in the relevant intervals, either contain the lower part of the grayish red, calcareous claystone or the upper part of the underlying grayish limestone and greenish claystone, both of the Cat Gap Formation. The co-occurrence of the two foraminifer taxa in these DSDP Sites is estimated to be in the Kimmeridgian, probably ranging upward into the Tithonian (Gradstein, this volume). This age estimate agrees with the geomagnetic reversal age estimates proposed by J. Ogg (this volume). 
Table 1. Multiple bio-, chrono-, and physical stratigraphy of Jurassic strata at DSDP Site 534, western North Atlantic Ocean.

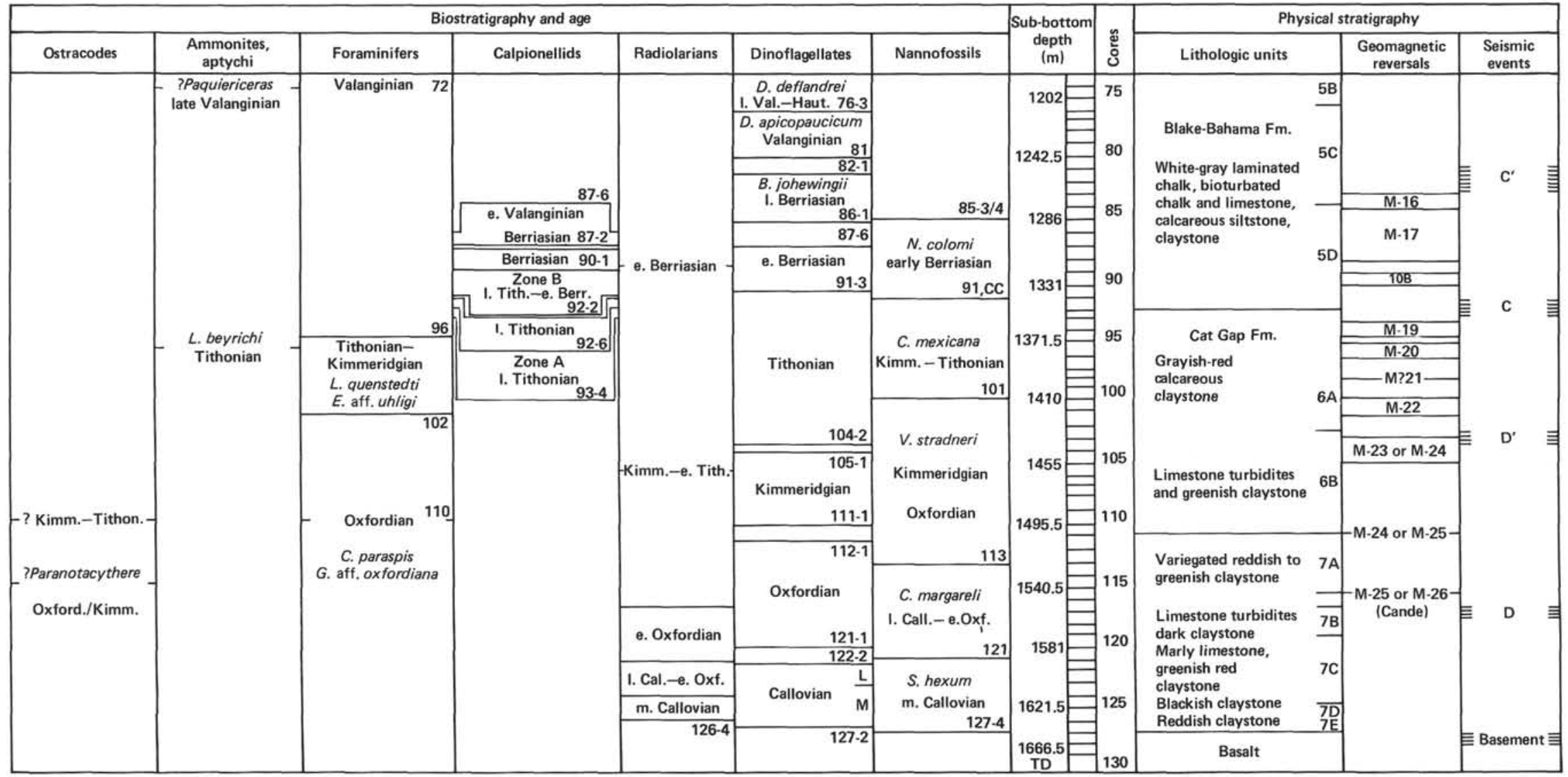




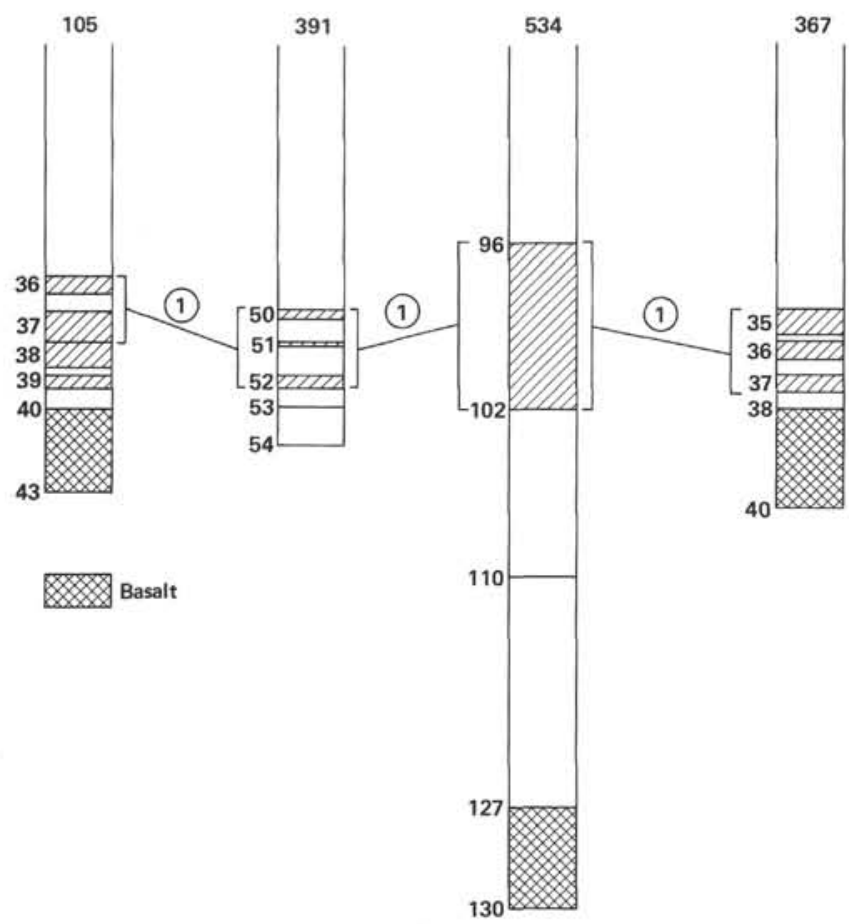

Figure 6. Correlation of the co-occurrence of the foraminifers Lenticulina quenstedti and Epistomina aff. uhligi (1) in DSDP Sites 105, 391,534 , and 367, North Atlantic Ocean. (In Site 534 this interval contains magnetic reversals $\mathrm{M}-20$ to $\mathrm{M}-24$ [Ogg, this volume], which agrees with the fact that at both Sites 105 and 367 basement is of approximately M-25 age and the overlying sediments should be slightly younger. The age of the $L$. quenstedti and $E$. aff. uhligi assemblage is estimated in these Sites to be Kimmeridgian, extending into the Tithonian [Gradstein, this volume].)

Using dinoflagellate stratigraphy, the basal sedimentary assemblage at Site 105 correlates to the palynological Kimmeridgian in Site 534 (D. Habib, personal communication, 1982). Such a correlation fails to explain why at Site 534 the palynological Kimmeridgian (Cores 111-105) occurs several cores below the interval with the mentioned foraminifers. The answer to this discrepancy in correlation is not easily found. As a next step, it would be useful to study point correlations of first and last occurrences and of co-occurrences of many taxa in different microfossil groups together with geomagnetic reversal sequences at the DSDP Sites. Such an approach may tell if ranges are incomplete or if some correlations are more likely to be "time lines" than others.

This correlation problem is but one of several that hamper a straightforward chronostratigraphic interpretation of the Oxfordian through Kimmeridgian interval at Site 534 and other DSDP sites as well (see Table 1). The most striking discrepancy appears to be the offset by five or more cores of the palynological and nannofossil late Oxfordian through early Tithonian interpretations, the palynological one being ahead in time. Again, no easy answers come to the fore, although it may be of significance that three samples from the late Oxfordian Hauffianum Zone, in the Montejunto section in Central Portugal (collected by F. M. Gradstein), were tentatively assigned to the early Kimmeridgian using some dinoflagellate taxa, also known from western Europe. The Portuguese Hauffianum Zone foraminifer assemblage, with a globigerinid resembling Globuligerina oxfordiana and Epistomina mosquensis, correlates at Site 534 to Core 110, where it is assigned to the Oxfordian (Gradstein, this volume). Geomagnetically this core is at the level of M-24 or M-25 of the latest Oxfordian to the earliest Kimmeridgian (Channell et al., in press). Such a correlation is not necessarily in disagreement with the $V$. stradneri nannofossil assemblage (Oxfordian-Kimmeridgian) in Cores 113 through 101, or the palynological Kimmeridgian as deep as Core 111. We may be dealing with the well-known boundary effect of biozonal stratigraphy, that is, uncertainty intervals are not usually given to the boundaries of conventional biozones. It would be more realistic to use a notation that would better reflect inaccuracies in the correlation of zonal limits.

The excellent fit of the Hole 534A sequence of Jurassic age-depth assignments bears out this "inaccuracy" interpretation (see the section on subsidence and sedimentation; Fig. 9). A careful evaluation of the relative correlation of bio- and magnetostratigraphic events, zones, or assemblages in oceanic and land sites should be helpful to understand this inaccuracy in time better.

\section{IMPLICATIONS FOR EARLY SPREADING RATES AND THE AGE OF THE BLAKE SPUR MARINE MAGNETIC ANOMALY}

Using the Armstrong (1978) numerical scale, we found that the seafloor magnetic reversals in Figure 7 are best fitted using two doglegs. Spreading proceeds at $3 \mathrm{~cm} / \mathrm{yr}$. from the Callovian-Oxfordian, which coincides exactly with the Jurassic Magnetic Quiet Zone (Channell et al., in press), after which spreading slows down somewhat to $2.4 \mathrm{~cm} / \mathrm{yr}$. For the Cretaceous, the Armstrong (1978) absolute time scale does not have reasonable proportions, for example, the Albian is excessively long and the Aptian almost "squeezed out." Therefore, the Armstrong scale was not used for the Cretaceous in Figure 7. If the spreading rate curve is extrapolated using the updated van Hinte scale (1976a), spreading slows down even more than $2.4 \mathrm{~cm} / \mathrm{yr}$. for the Early Cretaceous.

In the preferred new numerical scale (Fig. 5), early spreading appears as reasonably constant at $3.1 \mathrm{~cm} / \mathrm{yr}$. from $\mathrm{M}-28$ to $\mathrm{M}-17$ to $\mathrm{M}-16$ at the onset of the Cretaceous, after which the rate slows down to about 1.7 $\mathrm{cm} / \mathrm{yr}$. until the Aptian.

In both scales extrapolation to the Blake Spur Magnetic Anomaly (BSMA), $100 \mathrm{~km}$ landward of M-28 at Site 534, appears to yield the same age. The age derived is near the Bathonian/Callovian boundary, or approximately $155 \mathrm{Ma}$, which is about two stages or 20 m.y. younger than thought in previous publications, such as the determinations of Vogt and Einwich (1979), Bryan et al. (1980), and Klitgord and Grow (1980). Extrapolation is aided by the pinch-out position of seismic Horizon D, dated at Site 534 as early Oxfordian. Because Horizon D pinches out on basement just landward 


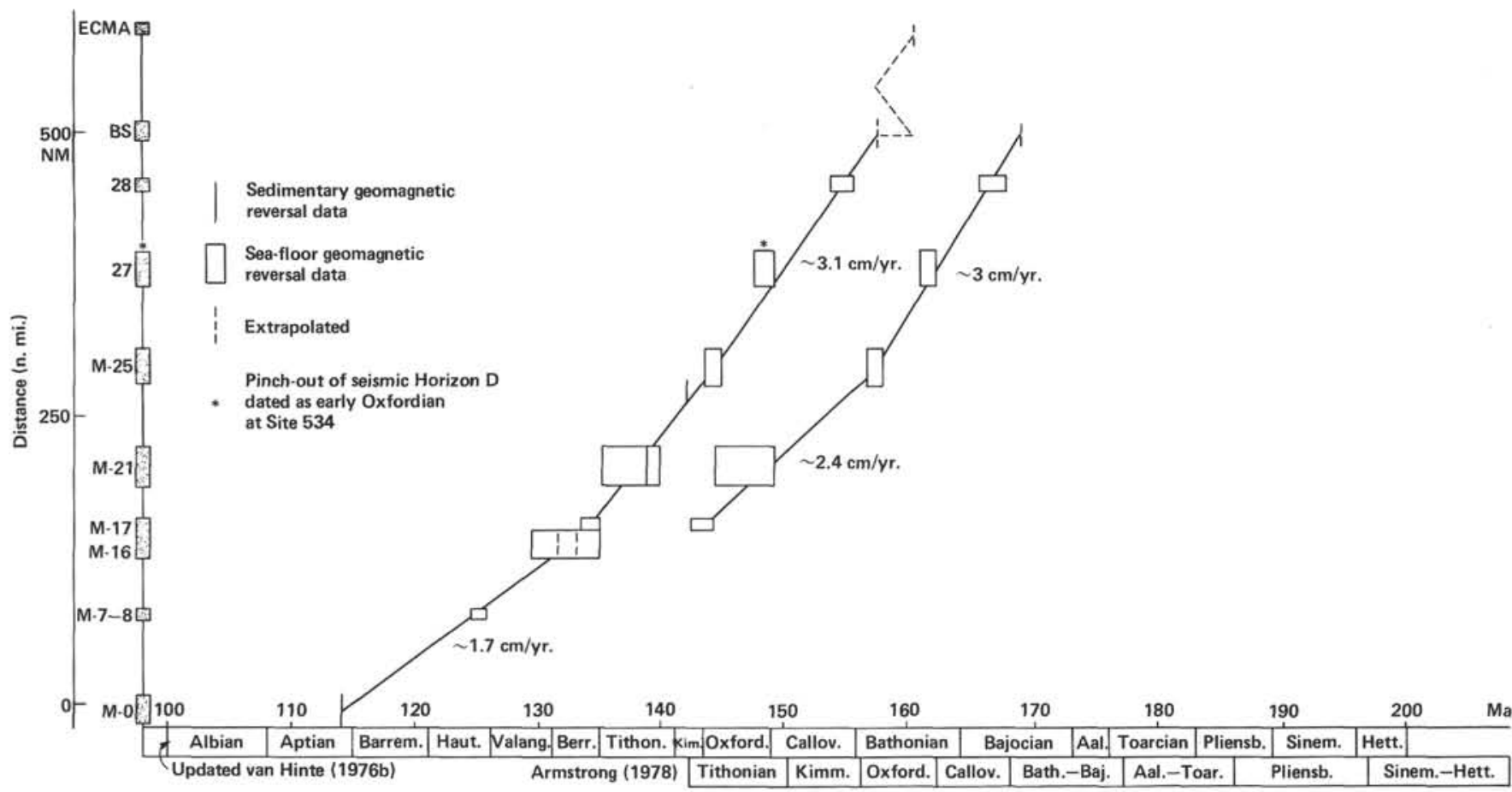

Figure 7. Rates of early Atlantic Ocean seafloor spreading during the time of the Blake Spur Magnetic Anomaly (BSMA) to geomagnetic Anomaly M-0. (We assume a ridge jump at the time of the BSMA. The preferred time scale has been updated from van Hinte [1976b], which gives an early spreading rate of $3.1 \mathrm{~cm} / \mathrm{yr}$. and a Cretaceous rate of $1.7 \mathrm{~cm} / \mathrm{yr}$. Using the Armstrong [1978] scale, early spreading slows from about 3 to 2.4 $\mathrm{cm} / \mathrm{yr}$, and becomes even slower in the Cretaceous. Both time scales predict the age of the BSMA to be of the Callovian/Bathonian boundary.)

of magnetic Anomaly M-27, as noted by Bryan et al. (1980), this aids in the extrapolation by providing another independent point in the Magnetic Quiet Zone.

The new age for the BSMA means that it might match reversals older than the Jurassic Magnetic Quiet Zone (Channell et al. in press). However, the paleomagnetic stratigraphy on the land section may produce a conflict, because reversals occurred during the Bathonian (Channell et al., in press). As indicated by Sheridan (this volume), there is great uncertainty in the age of the inner part of the Jurassic Marine Magnetic Quiet Zone between the Blake Spur Anomaly and the East Coast Magnetic Anomaly. It could be anything older than Callovian, from Bathonian through Pliensbachian. The problem is that there are no strong linear magnetic anomalies in this corridor that resemble seafloor reversal anomalies. Although the stratigraphy of the Bathonian to Pliensbachian land sections is not precise, they can be distinguished on a stage level, and there are enough sections measured that most people agree that there are magnetic reversals during these stages (Channell et al., in press; Steiner, 1980).

Perhaps the easiest way to avoid the conflict is to accept the possibility put forward by Sheridan (this volume) that the inner quiet zone corridor could also have spread very rapidly, similar to the outer quiet zone. Because this corridor contains both sides of an extinct spreading center, if the proto-Atlantic concept is right, only the upper part of the Bathonian stage might be represented by this crust. From the data presented by Channell et al. (in press), it is more certain that reversals are measured in the bottom part of the Bathonian, but the age span of the upper part of their section is uncertain.

If we do not accept this alternative and interpret the ECMA-BSMA (East Coast-Blake Spur magnetic anomalies) corridor to be possibly as old as the Pliensbachian, then we must explain the lack of seafloor magnetic anomalies. It might be that rapid sedimentation during the spreading created thick sediment and sill intercalations, as occurred in the Gulf of California, and because of the particular cooling regime of the sills, the magnetic grains formed with a low magnetization. Such an explanation was once invoked to explain the outer magnetic quiet zone. With the recovery of basalt at Site 534, such explanations are no longer viable. Steiner (this volume) finds that the basalts are well magnetized, with magnetizations no different from typical oceanic basalts of many ages. Unusually viscous remanence is probably not the cause of the outer magnetic quiet zone. Another explanation for the lack of magnetic anomalies in the ECMA-BS corridor, and for the possibly equivalent crust under the Gulf of Mexico, is that the basement is so deep that the amplitude of the anomalies is expected to be low. However, recent magnetic surveys show that the M-sequence anomalies persist as much as $100 \mathrm{~km}$ landward of the Japan Trench axis where the basement source must be some $15 \mathrm{~km}$ deep (von Huene et al., 1982). The resilency of these anomalies is thus demonstrated.

Another alternative is that the crust in the ECMA-BS corridor is of anomalous nature and not simply oceanic. Sheridan et al. (1979) considered the seismic refraction 
data in the corridor and these seem to be compatible with those of the outer quiet zone, which is clearly acceptable as oceanic crust. However, crustal velocities and thicknesses cannot be interpreted uniquely near to the edge of a continent that has been rifted, with a thinned and possibly dike-intruded crust forming the transition to oceanic crust. Observations on stretched, listric-faulted continental crust show thicknesses of about $5 \mathrm{~km}$ and depths to mantle of around $13 \mathrm{~km}$, which are nearly identical to the same features of oceanic crust. Thus crustal velocity and thickness and depth to mantle are not unique criteria to define oceanic crust.

Sheridan et al. (1979) also note that reflection profiles in the ECMA-BS corridor reveal a "typical" hyperbolic reflector characteristic of the oceanic basement of layer 2. This reflector might be stronger evidence that this corridor is truly oceanic. Certainly there are no indications in the presently available data that tilted blocks of the listric-faulted type, often associated with continental crust, are found in the ECMA-BSMA corridor. But until drilling is carried out west of the Blake Spur Anomaly this uncertainty about the nature of crust in the ECMA-BSMA corridor will persist.

\section{IMPLICATION OF THE AGE OF THE BLAKE SPUR MAGNETIC ANOMALY FOR THE EVOLUTION OF THE NORTH AMERICAN MARGIN}

The new Callovian/Bathonian boundary age for the Blake Spur Marine Magnetic Anomaly has significant application to the evolution of the North American margin. A spreading-center shift to this anomaly position, which would isolate the proto-Atlantic extinct rift on the North American plate, has been proposed as a mechanism to explain the East Coast Magnetic Anomaly-Blake Spur corridor (Sheridan, this volume).

Assuming reasonably rigid plates in the reconstruction of the Atlantic margin and the Gulf of Mexico, we expected that when spreading began along the ECMA that spreading should have occurred in the Gulf of Mexico as well. Thus the proto-Atlantic in the ECMA/ BSMA corridor should have had an equivalent opening in the Gulf of Mexico. But most researchers studying the Gulf of Mexico believe the ocean spreading breakup of that basin occurred later in the Jurassic than the age of the crust in the ECMA-BSMA corridor, previously thought to go back to the Pliensbachian. To resolve this difference, Salvador and Green (1980) propose that the first opening of the ECMA-BSMA corridor was more east-west, and that a transform fault ran through the Gulf of Mexico. This event would have allowed a protoAtlantic Ocean to exist off the eastern United States before the oceanic Gulf of Mexico. However, recent reconstructions of the African and North American continents, based on possible fracture zone interpretations in the ECMA-BS corridor, contradict the east-west movement. K. D. Klitgord and H. Schouten (personal communication, 1981) prefer a northwest-southeast opening better.

Now that this Blake Spur event is made younger by our dating, it might be young enough to have occurred after, rather than before, the breakup of the Gulf of Mexico, which formed a small ocean crust between the previously continuous Louann and Mexican salt basins (Salvador and Green, 1980). Although critical to dating this breakup, the age of the Louann salt is uncertain. It could be Bathonian, as suggested by Todd and Mitchum (1977). The overlying marine limestone of the Smackover Formation is part of the main transgressive sequence. It is well dated as Oxfordian. Although the Norphlet Formation of sands, between the Smackover and the underlying Louann, is poorly fossiliferous and its age is not well know, there are shaly facies that indicate the beginnings of the major transgression. P. R. Vail (personal communication, 1981) feels that these shales represent the Callovian transgression seen on the North Atlantic margins. Thus the Callovian is thought to overlie the Louann salt. Pollen microfossils from the Louann give a general age of the Middle Jurassic and are not definitive to the stage level.

In another interpretation the age of the Louann salt is thought to be Callovian (A. Salvador, personal communication, 1981). If one assumes that the sea-water source for the salt entered the Gulf of Mexico from the Pacific rather than the Atlantic, the earliest marine limestone above the salt in Mexico should be Callovian. If this Callovian limestone was deposited immediately after the Louann salt, then the age of the salt can be interpreted to be Callovian (Salvador, personal communication, 1981). Such a logical deduction is required, because a hiatus in deposition above the salt would expose it to solution in either marine or nonmarine conditions, so its mere preservation seems to require continuous deposition.

Given the uncertainty about the age of the Louann salt, it is possible that the opening of the Gulf of Mexico occurred in the late Bathonian. Note that this is also the time that could be assigned to the breakup along the ECMA. Thus with the new dating of the Blake Spur Anomaly as earliest Callovian, this major spreading shift could have occurred after the breakup of the Gulf of Mexico.

A major spreading center shift was needed to terminate spreading in the Gulf of Mexico and to allow breakup along the southeast margin of the Yucatan peninsula (Sheridan, this volume). Also, the breakup and spreading of the Yucatan away from South American would have permitted the formation of a Late Jurassic Caribbean Sea, which most Caribbean experts would like to postulate. It is now possible that the spreading center shift to the Yucatan margin to end the Gulf of Mexico spreading was one and the same event as the spreading center shift to the Blake Spur Anomaly that ended the proto-North Atlantic spreading. Further drilling in the deep Gulf of Mexico and ECMA-BSMA corridor is required to test these speculations.

\section{PULSATION TECTONICS}

Sheridan (this volume) has put forward a theory to explain the origin of the magnetic quiet zones in terms of cyclic plume eruptions from the core/mantle boundary, and alternations of the heat transfer mechanisms in 
the lower mantle between a conductive state (little or no plumes) and a convective state (many plumes). These variations of plume convection altered the temperature at the core/mantle boundary and, thus, the stability of the outer core. During plume eruptions the core is cooled while the asthenosphere is heated, which leads to a quiet magnetic field associated with a fast platespreading interval. In the absence of plume eruptions, the mantle is not convective but conductive and insulates the core, making it hotter. This leads to a cooler asthenosphere and slower plate spreading during times of a metastable, turbulent convecting core, which manifests itself in frequent magnetic field reversals.

A cooler core with more laminar core convection would be compatible with both an extended period of constant polarity and a weaker dipolar field measured at the surface. There is evidence for both of these phenomena during the Jurassic Quiet Zone (Channell et al., in press; Steiner, 1980). Also, in the Cretaceous Quiet Zone there is a well documented extended period of constant polarity.

\section{SUBSIDENCE AND SEDIMENTATION}

A detailed outline of the history of subsidence at Site 534 offers a unique opportunity to study ocean basin depositional history at an unprecedented scale. First, the sediment at Site 534, cored continuously from the lower Miocene through the middle Callovian, spans almost $160 \mathrm{~m}$.y. of ocean history. Second, it is only $22 \mathrm{~km}$ away from Site 391, where Tithonian through Recent sediments were recovered that comprise $140 \mathrm{~m} . \mathrm{y}$. of history. A comparison of the subsidence curves for both sites may be scrutinized for local variations in long-term depositional history. The mapping and understanding of these variations ultimately will considerably refine Mesozoic-Cenozoic paleoceanography.

Principal uncertainties in the determination of sediment accumulation rates are (1) uncertainty in sampling and observers' bias in biostratigraphic or magnetostratigraphic zone assignments, (1) uncertainty regarding the relation of the bio- or magnetostratigraphic zonations to the numerical, geochronological scale, (3) uncertainty of $5 \%$ or more in the radiometric dating of stratigraphic horizons, (4) uncertainty that the whole time interval of a zone is represented at the site (i.e., was there continuous or episodic sedimentation?), (5) uncertainty about the amount of erosion as opposed to nondeposition, and (6) uncertainty about the exact amount of compaction through time.

Error due to personal bias, reworking of microfossil occurrences, or sampling can be minimized through the use of multiple biostratigraphy and decreases with an increase of sampling points. An arbitrary way of representing this error and the numerical calibration error is by assuming that at each point on the average sedimentation path per zone (i.e., the diagonals $A B$ and $C D$ in the zone-time interval boxes in Fig. 8), an error exists of $50 \%$ of the duration of each zone. From this assumption follows the likely sedimentation rate pathway (in gray) in Figure 8 . Within the pathway the rate fluctu-

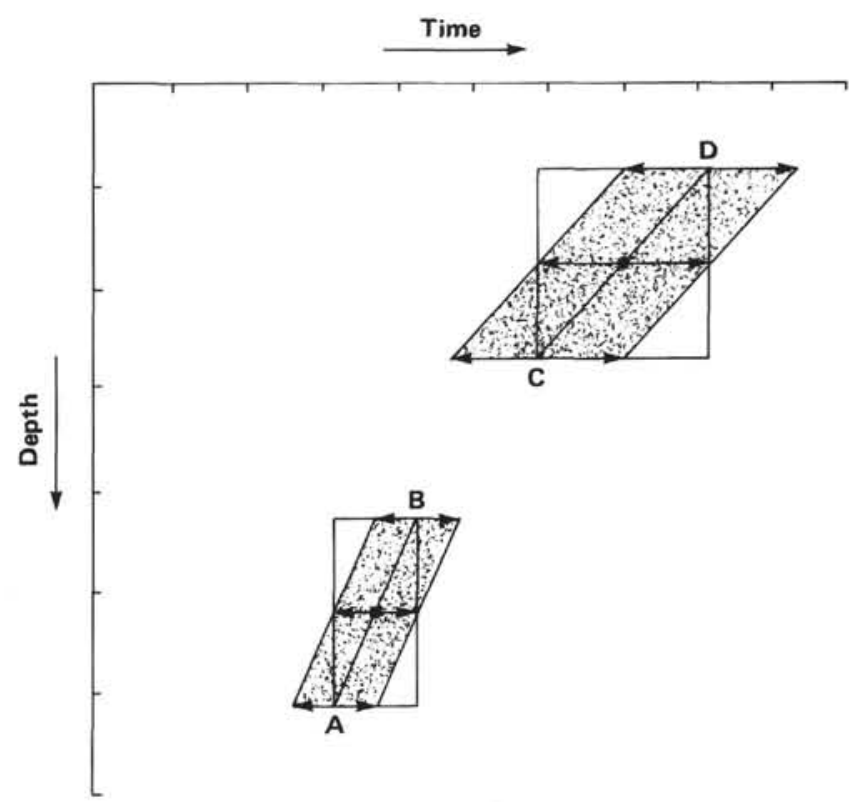

Figure 8. Likely pathway (in gray) of sediment accumulation per zone. (The square boxes represent the time-thickness range of biozones. For explanation see text.)

ates, but the average is given by inclination of the pathway.

Continuous versus episodic sedimentation and particularly erosion are factors that are difficult to assess. The error is inversely related to the biostratigraphic resolution. Average sedimentation rate per biozone is more realistic the shorter the duration of the zone in time. Otherwise these factors will have to be evaluated individually at each site and are a function of the depositional regime. Average sedimentation rates are clearly more representative and meaningful for hemipelagic and pelagic sedimentation than for turbidites or debris flows. This chapter only uses average rates of sedimentation.

The decompaction can be calculated from $h_{1}=h_{0}$ $\left(\varrho_{0}-\varrho_{w} / \varrho_{1}-\varrho_{w}\right)$ per depositional interval, where $h_{0}$ is the measured thickness in $\mathrm{m}, \varrho_{0}$ is the measured density of the sediment in $\mathrm{g} / \mathrm{cm}^{3}, \varrho_{w}$ is the density of seawater (1.028), and $\varrho_{1}$ is the estimated original density of the compacted sediment $(\sim 1.8)$. Residual errors may be of the order of $10 \%$.

Probably the single, largest error in the technique of establishing sediment accumulation rates is in estimating the numerical age of each biozone. The error in biochronology, that is, the fixation of successive zonal or first and last stratigraphic occurrence events to the ordinal, time scale, is proportional to (1) radiometric errors, (2) the spacing of the events in time, and (3) the synchroneity of the events and their correlative ones to radiometrically dated calibration points. The $30-50 \mathrm{mi}-$ cropaleontological zones, aided by a detailed magnetic reversal scale, in the Cenozoic (65 m.y.) theoretically allow for a local relative time stratigraphic resolution of better than 1 to $2 \mathrm{~m}$.y. In the Cretaceous and particularly in the Jurassic, far greater uncertainty exists. A 5\% 
radiometric error for numerical ages between 65 (top Cretaceous) and 200 (base Jurassic) m.y. gives values of 3 and $10 \mathrm{~m} . \mathrm{y}$.

One advantage in dealing with these errors is that the sediment accumulation technique is based on trends, that is, a line is used to average changes. Gross rates are fixed between successive points in time. The more midpoints that are known in the sediment accumulation curve, the better the determination of the successive rates. Single point errors in age or depth assignments do not detract much from the overall trends. Let us assume for a moment that one tie point to the numerical time scale of a succession of biostratigraphic events is $5 \mathrm{~m} . \mathrm{y}$. in error, that is, too old. This is compensated for by shifting all previous points between the erroneous one and the next firmly established younger one. The sum of the individual shifts of points is $5 \mathrm{~m} . \mathrm{y}$. Problems mainly occur when one tries to compare individual, short-term fluctuations in rate, within one site or between sites, at the level of maximum stratigraphic resolution available.

\section{Sediment Accumulation at Site 391}

The biostratigraphic criteria used to arrive at the sediment accumulation for Site 391 of Figure 9 are based on the (1) nannofossil, (2) foraminifer, and (3) palynological zonations as compiled in Gradstein et al. (1978). Advantage has been taken of minor new information. Cores 391C-6 and -7 are now dated as late Albian through early Cenomanian rather than Albian (Jansa et al., 1979), and the zonation of P. Roth for Leg 76 (this volume) is used to update slightly the Leg 44 results by the same author. Table 2 shows the numerical age of the top and

Table 2. Geochronology at Site 391, Blake-Bahama Basin.

\begin{tabular}{|c|c|c|c|}
\hline $\begin{array}{l}\text { Numerical age } \\
\text { (m.y.) }\end{array}$ & $\begin{array}{l}\text { Sub-bottom } \\
\text { depth } \\
\text { (m) }\end{array}$ & $\begin{array}{l}\text { Numerical age } \\
\text { (m.y.) }\end{array}$ & $\begin{array}{l}\text { Sub-bottom } \\
\text { depth } \\
\text { (m) }\end{array}$ \\
\hline 0 & 0 & 92 & 677 \\
\hline 1.8 & 149 & 104 & 780 \\
\hline 4.5 & 150 & 107 & 830 \\
\hline 6 & 149 & 107 & 925 \\
\hline 8 & 210 & 108 & 830 \\
\hline 11 & 210 & 113 & 905 \\
\hline 11 & 210 & & \\
\hline 12.5 & 259 & 113 & 990 \\
\hline 13.5 & 320 & 113 & 1010 \\
\hline $13-14.5$ & 325 & 116 & 1020 \\
\hline 14.5 & 326 & 119 & 1000 \\
\hline $15-16$ & 335 & 119 & 1030 \\
\hline 15.5 & 364 & 121 & 1090 \\
\hline 15.5 & 335 & 126 & 1125 \\
\hline 17 & 421 & 128.5 & 1210 \\
\hline 17 & 475 & 128.5 & 1220 \\
\hline 17 & 500 & 130 & 1200 \\
\hline 19.5 & 544 & 131 & 1260 \\
\hline 19.5 & 573 & 133.5 & 1270 \\
\hline \multirow[t]{2}{*}{22.5} & 582 & 133.5 & 1300 \\
\hline & & 136 & 1325 \\
\hline 23.5 & 600 & 138 & 1325 \\
\hline \multirow[t]{4}{*}{24} & 649 & 138 & 1340 \\
\hline & & 138 & 1390 \\
\hline & & 142 & 1400 \\
\hline & & 142 & 1412 \\
\hline
\end{tabular}

bottom of the zones used to plot the multiple age-depth relationship depicted in Figure 9. Precision of tops and bottoms of the zones was plotted to the nearest 0.5 m.y., but is clearly arbitrary.

No significant compaction has been assumed for the late Tertiary interval as densities are probably between 1.85 and $2 \mathrm{~g} / \mathrm{cm}^{3}$. The rates of accumulation of the decompacted and the compacted sediment in $\mathrm{cm} / 10^{3} \mathrm{yr}$. are shown in Table 3. The rates are also plotted in Figure 9 , together with some error bars, as explained before. Clearly defined fluctuations in the late Mesozoic-Cenozoic sedimentation rate are indicated. For the Tithonian-Barremian shaly limestones of the Cat Gap and Blake-Bahama Formations, rates are in the order of 1.7 $\mathrm{cm} / 10^{3} \mathrm{yr}$. (compacted) and 2.5 to $3 \mathrm{~cm} / 10^{3} \mathrm{yr}$. (decompacted). Because pelagic sedimentation plays an important role, this is a reasonable average figure. Sedimentation drops to slightly lower values of 0.8 to $1.1 \mathrm{~cm} / 10^{3}$ yr. (compacted) and 0.9 to $2.7 \mathrm{~cm} / 10^{3} \mathrm{yr}$. (decompacted) in the mid-Cretaceous when the greenish black and variegated colored clays were formed. Sedimentation may have been relatively steady. The question of the Late Cretaceous-Paleogene sediment starvation and/ or erosion is discussed later. The interclast chalk and siliceous-calcareous mudstone interval of the Miocene Great Abaco Member shows dramatic changes in rates from 1.1 to $11.6 \mathrm{~cm} / 10^{3} \mathrm{yr}$. The sparse coring in this alternation of debris flows and background pelagites and "contourite" deposits prevents the determination of a realistic depositional rate for each component. Obviously rapid changes in rate took place.

The Pliocene may have been a time of nondeposition and/or erosion. The uppermost Miocene to Pleistocene contact is in Core 3 at $150 \mathrm{~cm}$; it can be erosional. This erosional event may be the same as observed at Site 533 on the Blake Ridge at the end of the Pliocene, and probably is the result of an intensification of bottom currents. The Pleistocene rate of $7.9 \mathrm{~cm} / 10^{3} \mathrm{yr}$. is almost identical to the rate of $8 \mathrm{~cm} / 10^{3} \mathrm{yr}$. determined with greater precision at Site 533, many miles to the north.

Table 3. Compacted and decompacted sedimentation rates at Site 391, Blake-Bahama Basin.

\begin{tabular}{ccc}
\hline \multirow{2}{*}{$\begin{array}{c}\text { Interval } \\
(\mathrm{m})\end{array}$} & \multicolumn{2}{c}{ Sedimentation rate $\left(\mathrm{cm} / 10^{3} \mathrm{yr}\right)$} \\
\cline { 2 - 3 } & Compacted & Decompacted \\
\hline $1412-1200$ & 1.7 & 3.0 \\
$1200-1030$ & 1.7 & 2.8 \\
$1030-970$ & 0.9 & 1.4 \\
$970-780$ & 1.1 & 2.7 \\
$780-685$ & 0.8 & 0.9 \\
$685-649$ & - & - \\
$649-500$ & 2.1 & 2.1 \\
$500-325$ & 11.6 & 11.6 \\
$325-315$ & 7.3 & 7.3 \\
$315-205$ & 3.7 & 3.7 \\
$204-140$ & 1.1 & 1.1 \\
& ?Erosion & $?$ Erosion \\
$140-0$ & 7.9 & 7.9 \\
\hline
\end{tabular}

Note: Above $649 \mathrm{~m}$, measured sediment densities approach the uncompacted, average value of 1.8 . -indicates no data available. 


\section{Sediment Accumulation at Site $\mathbf{5 3 4}$}

The biostratigraphic criteria used in Figure 9 to arrive at the age-depth plot for Site 534 are based on nannofossil, foraminifer, radiolarian, calpionellid, dinoflagellate, and magnetostratigraphy data. This multiple stratigraphy and the resulting chronostratigraphic interpretation are summarized in Table 4, which makes use of the time scale constraints shown in Figure 5. Tables 4 and 5 contain the body of biostratigraphic-geochronological

Table 4. Thickness and duration of biostratigraphic zones, assemblages, and events in Hole 534A.

\begin{tabular}{|c|c|c|c|}
\hline Zone, assemblage or event ${ }^{\mathrm{a}}$ & $\begin{array}{c}\text { Core range } \\
\text { (core-section-core) }\end{array}$ & $\begin{array}{l}\text { Sub-bottom } \\
\text { depth } \\
\text { (m) }\end{array}$ & $\begin{array}{c}\text { Duration } \\
\text { (m.y.) }\end{array}$ \\
\hline S. heteromorphus (N) & 2 & $545-555$ & $15.5-17$ \\
\hline G. insueta $(\mathrm{F})$ & 3 & 565 & $16-17$ \\
\hline H. ampliaperta $(\mathrm{N})$ & 3,4 & $555-574$ & $17-18$ \\
\hline C. dissimilis $(\mathrm{F})$ & 7 & 593 & $18.5-19.5$ \\
\hline S. belemnos (N) & 5,6 & $574-593$ & $18-19$ \\
\hline T. carinatus $(\mathrm{N})$ & $7-18$ & $593-690$ & $19-22.5$ \\
\hline G. kugleri $(\mathrm{F})$ & $10-18$ & $593-660$ & $22.5-23.5$ \\
\hline D. barbadiensis $(\mathrm{N})$ & $19-21$ & $696-715$ & $37.5-43$ \\
\hline D. saipanensis $(\mathrm{N})$ & $19-21$ & $696-715$ & $37.5-43$ \\
\hline G. stuarti $(\mathrm{F})$ & $24-26$ & $741-764$ & $70-67$ \\
\hline S. echinoideum $(\mathrm{P})$ & $27-30$ & $764-802$ & $100-103$ \\
\hline l. Albian (?) (F) & 27 & 775 & $100-105$ \\
\hline S. vestitum $(\mathrm{P})$ & $32-36$ & $812-859$ & $103-106$ \\
\hline C. litterarius $(\mathrm{N})$ & 44 & $923-932$ & $113-115$ \\
\hline S. perlucida $(\mathrm{P})$ & $36-49$ & $850-972$ & $106-115$ \\
\hline$W$. oblonga $(\mathrm{N})$ & $45-58$ & $932-1053$ & $115-123$ \\
\hline C. cuvillieri $(\mathrm{N})$ & $59-70$ & $1052-1157$ & $123-126$ \\
\hline T. verenae $(\mathrm{N})$ & $71-77$ & $1157-1218$ & $126-129$ \\
\hline R. neocomiana $(\mathrm{N})$ & $78-84$ & $1218-1277$ & $129-132$ \\
\hline H. sigali $(\mathrm{F})$ & $52-53$ & $990-1008$ & 121 \\
\hline mid-Valanginian (F) & 71 & 1165 & 28 \\
\hline Zone $\mathrm{A}+1$. Tith. (C) & $92-6-93-4$ & $1347-1351$ & $135-138$ \\
\hline N. colomi $(\mathrm{N})$ & $85-93$ & $1277-1349$ & $132-135$ \\
\hline Zone B (C) & $90-7-92-2$ & $1322-1344$ & $133-137$ \\
\hline Berr.-e. Valang. (C) & $87-2-90-1$ & $1297-1323$ & $130-135$ \\
\hline C. mexicana $(\mathrm{N})$ & $91-102$ & $1331-1428$ & $135-141$ \\
\hline L. quenstedti (F) & $96-102$ & $1371-1428$ & $139-143$ \\
\hline Kimmeridgian $(\mathrm{P})$ & $105-111$ & $1446-1504$ & $141-143$ \\
\hline C. paraspis (F) & 110 & 1495 & $143-146$ \\
\hline Oxfordian (P) & $112-121$ & $1304-1590$ & $143-149$ \\
\hline e. Oxfordian (R) & $117-122$ & $1549-1594$ & $146-149$ \\
\hline S. hexum (N) & $123-2-127-4$ & $1590-1638$ & $149-154$ \\
\hline M. Call.-E. Oxford. (R) & $122-126$ & $1590-1630$ & $147-154$ \\
\hline $\mathrm{M}-16(\mathrm{M})$ & 84 & $1269-1276$ & 133 \\
\hline $\mathrm{M}-18(\mathrm{M})$ & 90 & $1321-1328$ & 135 \\
\hline M-20 (M) & 96 & $1373-79$ & 137 \\
\hline $\mathrm{M}-22(\mathrm{M})$ & $101-102$ & $1409-1421$ & 140 \\
\hline $\mathrm{M}-23 / 24(\mathrm{M})$ & $104-105$ & $1436-1450$ & $141-143$ \\
\hline M-24/25 (M) & $111-112$ & $1495-1506$ & $144-142$ \\
\hline M-28 (M) & $127-130$ & $1636-1666$ & $154-156$ \\
\hline
\end{tabular}

Note: Time scale is as used in Figure 5.

${ }^{a} \mathrm{~N}=$ nannofossils; $\mathrm{F}=$ foraminifers; $\mathrm{P}=$ palynomorphs; $\mathrm{R}=$ radiolarians; $\mathrm{C}=$ calpionellids; and $\mathrm{M}=$ geomagnetic reversals. interpretations and the original and decompacted thickness and compacted and decompacted sedimentation rate for average depositional intervals in Site 534. These intervals are determined from the points of gross change in rate. Further study will attempt to define the ratio of turbiditic versus background (nepheloid, pelagic, traction current) deposition to determine more realistic than average sedimentation rate values. Measured density values are as presented in the physical property studies (this volume); the values are corrected for postcoring decompaction.

Essentially, the sediment accumulation curve shows three broad trends. First, there is the remarkably constant average rate of 1.4 to $2.5 \mathrm{~cm} / 10^{3} \mathrm{yr}$. from the Callovian through the Albian. In 60 m.y. (155-100 Ma), about two-thirds of the sediment (decompacted $=1520$ $\mathrm{m})$ accumulated. This event was followed by a relative standstill for another 80 m.y., after which the last onethird accumulated in less than 20 m.y. A more detailed examination of the curve in light of known paleoceanographic and continental margin events over the last 150 m.y. explains at least part of this sedimentation pattern. The broad Callovian to Kimmeridgian eustatic highstand of the sea (Hallam, 1975), as, for example, expressed in the significant Callovian-Oxfordian transgressions or facies changes of part of the North Atlantic margins (Essaouira, Scotian, and Lusitanian basins), coupled with a low relief hinterland, caused little or no, coarser than clay-size, terrigenous clastic influx in the deepest part of the Atlantic deep basin. Most of the sediment is clay or carbonate. The basal black, green, and red shales were deposited at an average rate of $0.7 \mathrm{~cm} / 10^{3} \mathrm{yr}$. Such a rate compares well with the mid-Cretaceous black shale rate; it agrees with the phosphatic content, the fish ear bones, and high radiolarian content, which indicate slow sedimentation under possibly poorly oxygenated conditions. The finding of nannofossil-rich fecal pellets in thin section and poor benthic foraminiferal fauna indicates limited benthic life in the deep basin. Such limited benthic life may be due to local depressions of the seafloor rapidly creating low oxygen conditions when the sedimentation was rich in organic material and the circulation possibly restricted. The latter is quite conceivable in the earliest Central Atlantic Ocean, which might have had narrow passages to the Pacific in the west and to Tethys in the east and not much of a vertical and lateral temperature gradient. Alternatively, as mentioned in the discussion section of Habib's chapter (this

Table 5. Original and decompacted thickness, interval duration in time, and average compacted and decompacted sedimentation rates for Site 534 .

\begin{tabular}{|c|c|c|c|c|c|c|}
\hline \multirow{2}{*}{$\begin{array}{c}\text { Interval } \\
\text { (m) }\end{array}$} & \multirow{2}{*}{$\begin{array}{l}\text { Measured density } \\
\qquad\left(\mathrm{g} / \mathrm{cm}^{3}\right)\end{array}$} & \multirow{2}{*}{$\begin{array}{l}\text { Decompacted } \\
\text { thickness } \\
\text { (m) }\end{array}$} & \multirow[b]{2}{*}{ Age } & \multirow{2}{*}{$\begin{array}{l}\text { Duration } \\
\text { (m.y.) }\end{array}$} & \multicolumn{2}{|c|}{$\begin{array}{l}\text { Sedimentation rate } \\
\left(\mathrm{cm} / 10^{3} \mathrm{yr} .\right)\end{array}$} \\
\hline & & & & & Compacted & Decompacted \\
\hline $1639-1495$ & 2.5 & 275 & m. Callovian-Oxfordian & $154-144$ & 7.4 & 2.7 \\
\hline $1495-1420$ & 2.5 & 143 & Kimmeridgian & $144-141$ & 2.5 & 4.8 \\
\hline $1420-935$ & $2.6-2.4$ & 926 & Tithonian-Barremian & $141-115$ & 1.9 & 3.6 \\
\hline $935-775$ & 2.1 & 216 & Aptian-Albian & $115-100$ & 1.0 & 1.4 \\
\hline $775-690$ & 2.1 & 117 & Cenomanian-Oligocene & $100-22.5$ & 0.1 & 0.2 \\
\hline $690-593$ & 2.0 & 121 & early Miocene & $22.5-19$ & 2.7 & 3.4 \\
\hline $593-545$ & 2.0 & 60 & early-middle Miocene & $19-15.5$ & 1.4 & 1.8 \\
\hline
\end{tabular}



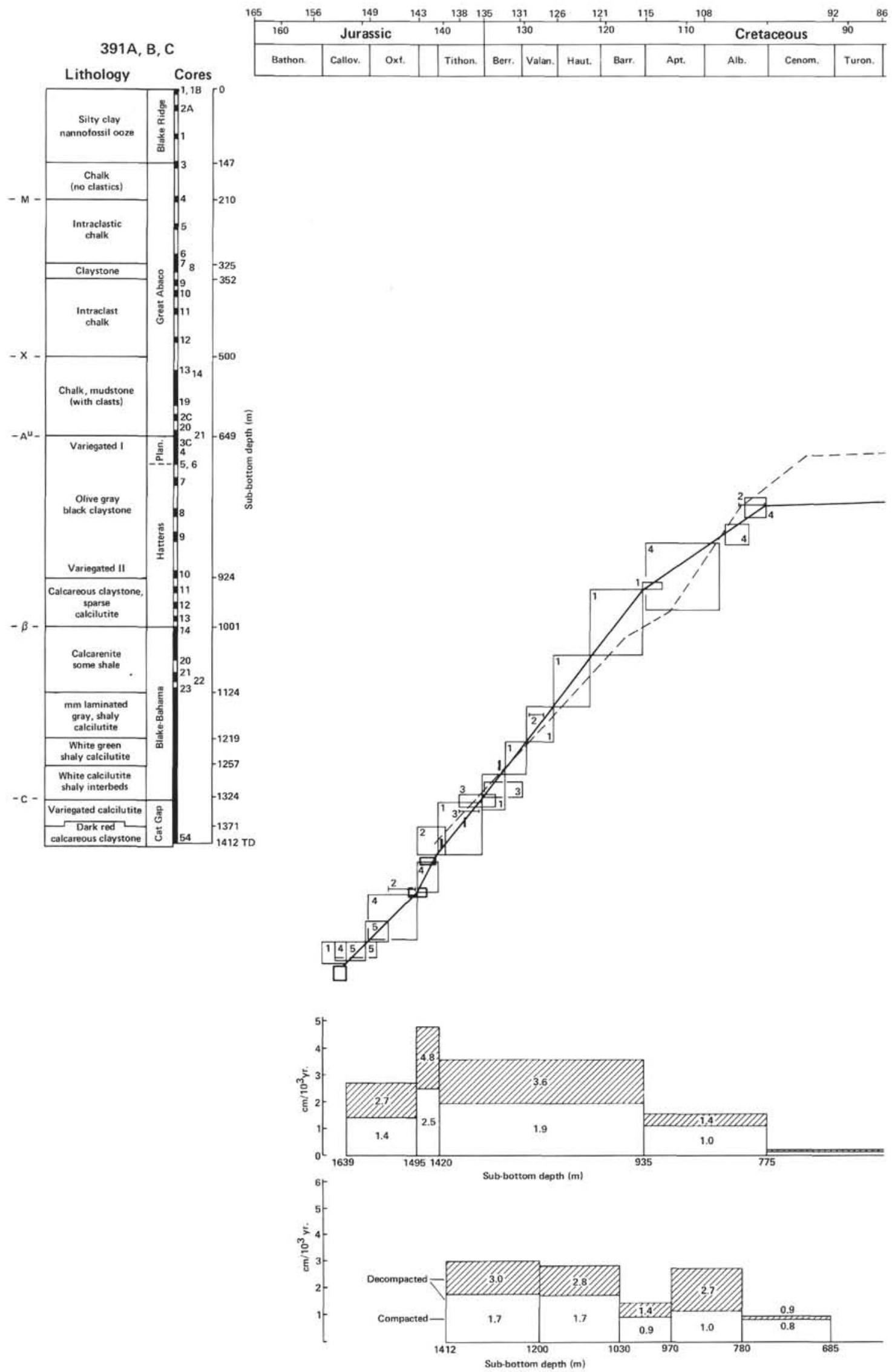

Figure 9. Sediment accumulation rates in DSDP Sites 534 and 391, Blake-Bahama Basin. (For explanation see text.) 


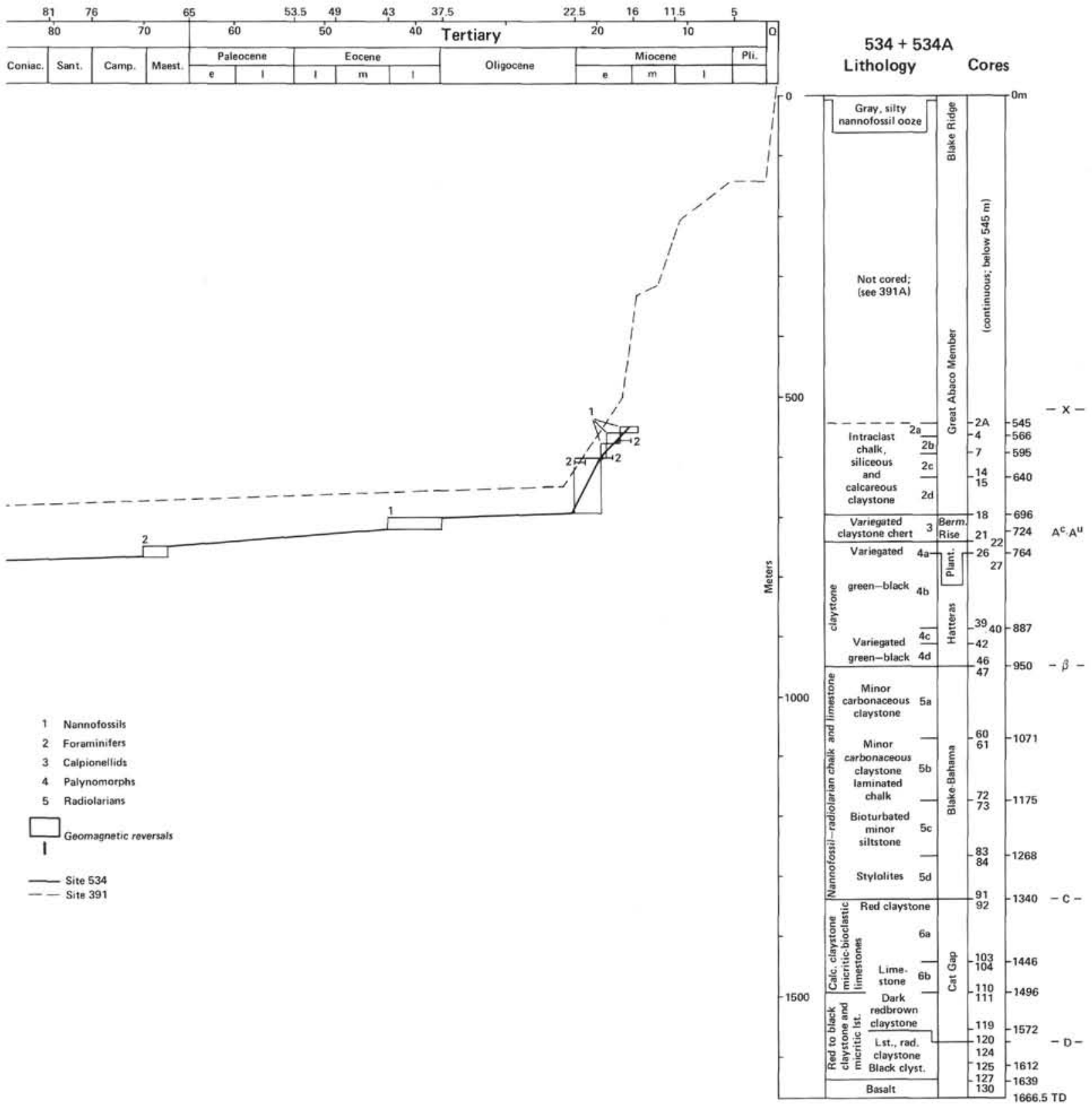

Hole 534A

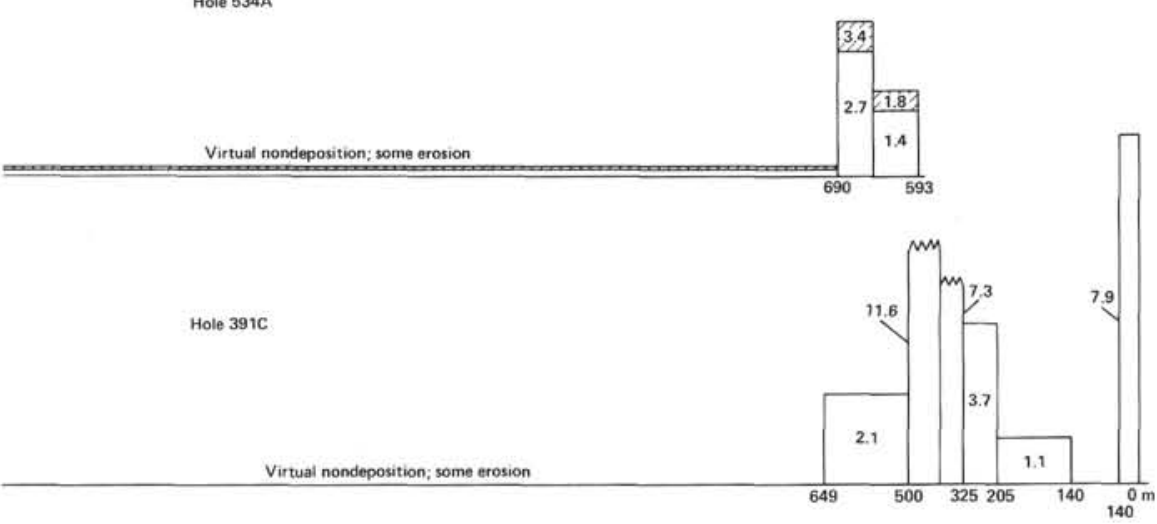

Figure 9. (Continued). 
volume), rapid deposition of terrigenous organic rich sediments and fecal pellets might lead to preservation of the organic matter even in oxygenated bottom waters. Thus the Callovian black shales could have deposited in more normal circulation conditions.

The overlying micritic and bioclastic limestones, reddish to green gray claystone, and radiolarian silt of the late Callovian through the Oxfordian bear strong evidence of turbiditic and probably current deposition. Periodically, the sedimentation rate was high for oceanic conditions, although the average value is only $1.4 \mathrm{~cm} /$ $10^{3} \mathrm{yr}$. The overlying Kimmeridgian through Tithonian red claystone only averaged 1.9 to $2.5 \mathrm{~cm} / 10^{3} \mathrm{yr}$. The sequence of "boxes and error bars" suggests that at the Jurassic/Cretaceous boundary sedimentation may have been even slower and, together with the low CCD, results in a high biomass with relatively rich ammonites and calcispherulid, calpionellid, and benthic foraminiferal assemblages.

There is no change from the Jurassic average rate in the Early Cretaceous when the pelagic and turbiditic limestones, chalk, and terrigenous clastics of the BlakeBahama Formation accumulated. Mid-Cretaceous rates of sedimentation of the Hatteras dark clays is again on the order of $1 \mathrm{~cm} / 10^{3} \mathrm{yr}$. (1.4 decompacted). By the time of maximum transgression of the continents in the Cenomanian, the Blake-Bahama Basin was a starved basin, remaining so until the Miocene. As we will argue later, it is unlikely that steady, Late Cretaceous-Paleogene accumulation occurred, only to be eroded in the Oligocene. There was a return to relatively rapid accumulation after the Oligocene, with large fluctuations in rate due to the debris-flow nature of the deposits. It is probably more than coincidence that somewhat similar "catastrophic" sedimentation is reported from the Moroccan margin (von Rad and Arthur, 1979).

The average rate of accumulation at Site 534 corresponds, within the range of error, to rates obtained for nearby Site 391 . The meaning of (1) a slightly higher overall rate in the Valanginian-Barremian Blake-Bahama Formation at Site $534,(2)$ a decrease in rate in the Aptian-Albian, and (3) the presence of the Eocene Bermuda Rise deposits will have to be evaluated after more detailed study.

\section{LATE CRETACEOUS TO PALEOGENE DEPOSI- TION OR NONDEPOSITION IN THE BLAKE-BAHAMA BASIN}

Maturation studies using vitrinite reflectance have yielded conflicting results on what happened during the Cretaceous-Miocene hiatus at Deep Sea Drilling Site $391,22 \mathrm{~km}$ southwest of Site 534. On the basis of a series of vitrinite reflectance data of the Cretaceous black shales and one data point in the immediately overlying Miocene chalks and clays, Dow (1978) has hypothesized that $800 \mathrm{~m}$ of meterial were removed from the Cretaceous section before the Miocene. An independent study by Cardozo et al. (1978) provides three more points for the Miocene interval that agree with the scant information from Dow (1978), but, unlike Dow, it fails to show a reflectance index in the Cretaceous strata higher than compatible with the present stratigraphic thicknesses. It is peculiar that Cardozo's et al. (1978) scatter of points in the Cretaceous shales shows a reflectance gradient with a negative intercept at zero depth; maybe their data has analytical errors. The lack of agreement between the two studies could be due to failure to differentiate satisfactorily between primary and secondary vitrinite particles. Clearly, there is a need to reexamine the vitrinite reflectance measurements in an attempt to reconcile the two conflicting depth versus reflectance profiles. Cretaceous palynomorphs at both Sites 391 and 534 are wellpreserved and translucent, suggesting a low level of thermal immaturity that requires no significant overburden. At best the $800 \mathrm{~m}$ of missing sediment should be considered an overestimate of the true value and is hard to reconcile with the slow net sedimentation rate for the Late Cretaceous-Paleogene found now at Site 534.

The new stratigraphic information from Site 534 provides significant constraints on the amount of deposition and erosion or nondeposition in the Late Cretaceous-Paleogene. At Site 534 there is no CretaceousMiocene hiatus. The mid-Cretaceous dark shale lies disconformably under the Maestrichtian variegated shale, which in turn is disconformably overlain by late Eocene zeolitic clay and chert. Miocene (debris flow) interclast chalk disconformably overlies the Eocene cherty formation. The total thickness of sediment present in the stratigraphic interval between the Albian and the Miocene is $68 \mathrm{~m}$. Obviously the section is much condensed and riddled with hiatuses. The metalliferous content of the Eocene variegated, zeolitic clays indicates that sedimentation was very slow (see also Robertson, this volume, on arguments against upward diffusion of metals from the underlying Hatteras shales), much less than in the mid-Cretaceous and Miocene.

What is now known of the Late Cretaceous-Paleogene paleoenvironment does not suggest that rapid deposition followed by drastic erosion occurred. The Maestrichtian and Eocene sediments are apparently not remnants of a much thicker section. Even if some erosion took place, for example, in the Oligocene when possibly there were drastic local changes in oceanographic conditions, it is extremely unlikely that prior buildup of much sediment could have occurred after the late Eocene. Hypothetical deposition of $800 \mathrm{~m}$ from the Late Cretaceous through the Paleogene would have required an average rate of sediment accumulation of $1.5 \mathrm{~cm} / 10^{3}$ yr., a rate similar to the earlier pre-Late Cretaceous. Rates of several orders of magnitude larger are in order if the stripped sediment had to fit in the time gaps at the disconformities. In all, the sedimentary information from Site 534 does not corroborate steady average sedimentation followed by profound (Oligocene) erosion. Late Cretaceous through Paleogene "starvation" appears more likely.

\section{JURASSIC PALEOGEOGRAPHY AND PALEOCIRCULATION}

The stratigraphic, sedimentologic, and seismostratigraphic record at Site 534 provides information on Jurassic water-mass circulation that will be reviewed in the 
light of the position of the widening Atlantic Basin relative to the Tethys and the Pacific Ocean. Figure 10 shows a generalized Jurassic stratigraphic framework (Lancelot and Winterer, 1980) in circum-Atlantic margin basins. Two regionally significant transgressions are shown, one in the postevaporite-dolomite basins of the Grand Banks, Portugal and Scotian Shelf, Morocco, dated as Sinemurian, and one in the Callovian-Oxfordian.

The margin sedimentation was always shallow marine; evidently sedimentation matched subsidence, as documented in Grand Banks wells (e.g., Gradstein et al., 1975). The sedimentary record in the marginal basins shows that the deep part of the Jurassic basin was confined to the slope and rise areas of the present ocean.

On the basis of the discussions presented in this chapter on the age of marine magnetic Anomaly M-28 (early Callovian) and of the Blake Spur Anomaly (Callovian/ Bathonian boundary), and on the nature and age of the Jurassic (marine) Magnetic Quiet Zone, we believe that the Atlantic Ocean did not open much before the Callovian. At that time the only deep oceanic basin was confined to the area of Site 534 in the western North Atlantic and to Site 416 in the eastern Atlantic. The deepening oceanic basin, then, was largely confined to the outer marine Jurassic Quiet Zone. Based on this postulate, we have reconstructed the Callovian through Kimmeridgian paleogeography of the central North Atlantic Ocean basin (Fig. 11A-C).

These reconstructions also show the extinct rift of the proto-Atlantic and Gulf of Mexico confined to the North American plate, and oceanic lithologies as found at DSDP Sites 534, 105, 416, 100, and, for comparison, in the pelagic Lombardy Basin (J. Ogg, personal communication, 1981) and the Ligurian Tethys (Lemoine, this volume).

On these reconstructions we show that the Middle and Late Jurassic surface water exchange between Tethys in the east, the incipient Central Atlantic Ocean, and probably the Pacific as well was unimpeded and relatively stable. Such circulation is evidenced by the rich Old World-type Middle and Late Jurassic nannofossil and radiolarian assemblages and by the filament-type facies at Site 534. The latter was even recorded from the silicified limestone laminae between individual basalt pillows of basement. Coeval Callovian beds in the Mediterranean are also rich in these filaments, which are derived from a floating pelecypod. The presence of Oxfordian planktonic foraminifers in Core 110, some of the oldest known (Gradstein, this volume), correlate to their finding in Oxfordian limestone blocks dredged from the Moroccan lower slope (Renz et al., 1975) and to an abundance peak in Oxfordian strata in the Mediterranean basin margins. Clearly the Central Atlantic, however narrow, originally underwent surface water exchange, as should be expected for a narrow ocean of the present Mediterranean Sea type.

The Saccocoma, Calcispherulid, Aptychi assemblage at the top of the Jurassic red claystones at Site 534 is well known from other sites in the western and eastern Central Atlantic $(100,105,367)$. It is typical of the pe- lagic facies of Tethys and attests to further free surface water exchange in the expanding ocean basin.

A reasonable model of surface circulation is based on actualistic observations of wind and current patterns in the equatorial belt. We use the reconstruction postulated by Ager (1975). In its near equatorial position and near east-west orientation, the embryonic North Atlantic formed an ideal passageway for the easterly trade winds of the Jurassic (Fig. 11). During the earliest stages, it is here interpreted that the surface currents through the North Atlantic were wind driven from Tethys to the $\mathrm{Pa}$ cific, and back into Tethys again with only a flow to the west.

It is speculated here that during the late Callovian through the Oxfordian, the North Atlantic widened to a point where the equatorial countercurrent was able to create return flow along the southeastern edge of the North Atlantic, which continued into the equatorial countercurrent flow along the southern edge of Tethys (Fig. 11). This equatorial current pattern persisted, we believe, until the overall Central Atlantic margin drifted north of $30^{\circ}$ latitude, perhaps in the Early Cretaceous, and then the effect of the westerly winds developed the clockwise North Atlantic gyre. Also, at about this time in the Cretaceous, access to the Pacific was closed by the movement of the Nicaraguan block into the Caribbean. This movement forced the trade wind currents to back up and veer northeast along the eastern North American margin. This was the beginnings of the Gulf Stream Current.

Biogeographic studies on Jurassic mollusks (e.g., Westermann \& Riccardi, 1976), and the review by Hallam (1975) fail to show more than an increasing latitudinal differentiation of faunas from the Middle to Late Jurassic. In the equatorial belt there was little or no evidence of a distinct eastern Pacific versus western Tethyan (Mediterranean) province as far back as the earliest Middle Jurassic. On the evidence of Middle and Late Jurassic marine epicontinental deposits in Cuba and particularly in Mexico (Barr, 1974; Kourdell, 1956), and Late Jurassic marine sediments in the Gulf of Mexico, Hallam (1975) and others favor a Central Atlantic pathway as early as the Bajocian. Rifting may have led to a pre-Callovian ocean pathway, and it is reasonable to assume this to be the Bajocian-Bathonian one. We may conclude that the new data from Site 534 agree reasonably with the ocean connections in the Middle Jurassic suggested by biogeographic data.

An assessment of Jurassic bottom circulation is more speculative, but we are aided by the discovery of black shales and current deposited or winnowed beds at Site 534. Organic- and phosphatic-rich sediments of Callovian age occur in Cores 125 through 127. Callovian deep circulation might have been weak and possibly temporarily restricted, the result of geographic barriers. A silled basin morphology due to the topographic relief of the then-existent ridge flank as seen on the seismic data is quite likely. Such a basin may have been a local feature, and if the dark shales result from local anoxia, they may be local as well. At present it is not possible to assess if the barriers were local or affected the basin as a 


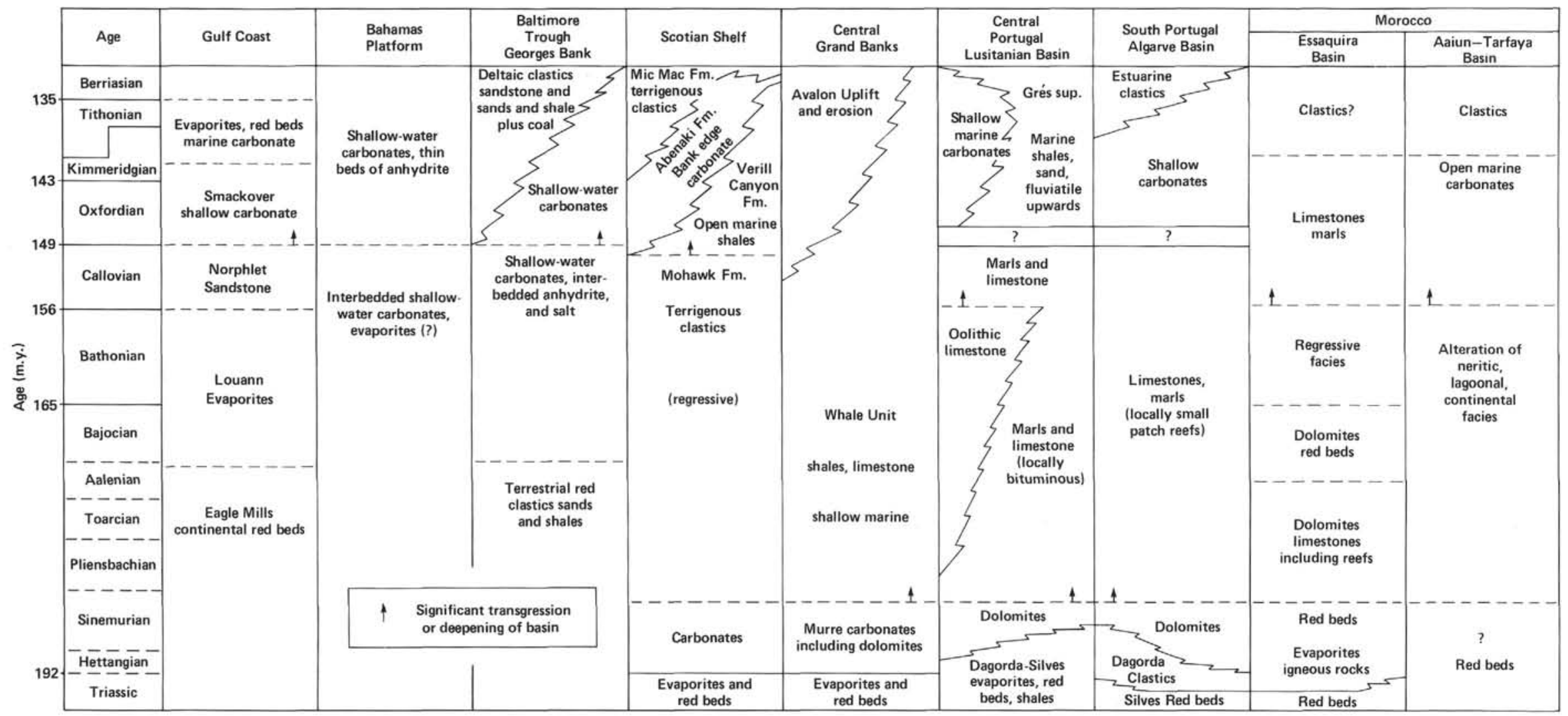

Figure 10. Generalized Jurassic stratigraphy (Lancelot and Winterer, 1980) in circum-Atlantic margin basins. 
whole. From seismic data it appears that the Callovian ridge flank topography was quite irregular and could have contained poorly ventilated lows. Once these lows could be reached by organic-rich debris from the margin, either by turbidite or weak cross-slope or alongslope currents, black shales accumulated.

Alternatively, the organic rich Callovian shales could have been deposited under normal oxygenated bottom waters (Habib, this volume) and in a formation analogous to the Hatteras Formation, which is of great regional extent. In fact the seismic data (Sheridan et al., this volume) reveal evidence of current-deposited sediments in the basement low near Site 534. Bottom currents may have circulated through this fracture zone trough.

Contrary to the poor ventilation hypotheses, the Callovian and Oxfordian ocean basin was not likely to have been inhospitable to bottom-dwelling organisms. A small-size, low-diversity agglutinating and calcareous foraminiferal fauna is seen in the cores, which is largely indigenous rather than swept in from the margin (Gradstein, this volume). The absence of provincialism in this abyssal benthic fauna, which for the Oxfordian-Kimmeridgian was remarkably similar to that found in DSDP sites in the eastern Atlantic and Indian oceans, indicates that the Central Atlantic Basin was a relatively open connection with Tethys and possibly the Pacific as well.

From the Callovian and lower-middle Oxfordian sediments comes sedimentological evidence for current deposition that indicates that at least temporary oceanfloor circulation and ventilation occurred. The sedimentary features that suggest transportation of the carbonate, organoclastic, and siliceous claystone "background" sediments of Unit 7 by weak bottom currents are: (1) more layers of well-sorted, silt-size particles, mainly of radiolarian tests; (2) thin bedding less than $5 \mathrm{~cm}$ in thickness, and lack of massive bedding; (3) sharp top and bottom contacts; (4) lenticular beds possibly of starved ripples; (5) graded beds; (6) preferred grain orientation parallel to bedding; (7) placer deposits of size-sorted microfossils and grains, many of them worn; (8) ubiquitous lamination; (9) measured $5^{\circ}$ to $10^{\circ}$ primary dips, in sets of up to $10 \mathrm{~cm}$ thick; (10) herringbone cross bedding; and (11) erosional surfaces.

All of these primary sedimentary features can be explained by bottom-current deposition. The fine-grained, silt- and clay-size hemipelagic sediments of Unit $7 \mathrm{can}$ be interpreted to have deposited from suspension in a turbid bottom-water layer, such as a nepheloid layer, which dumped bed upon bed in local mud wave structures creating low-angle relief on the seafloor. Penecontemporaneous slumping from these mud ridges caused local redistribution in swales.

Significantly, the high-resolution seismic reflection profiles at Site 534 show hummocky reflectors in an asymmetrical elongate mound feature beneath Horizon $\mathrm{D}$, which can be interpreted as current-deposited bed forms forming mud wave and ridge structures (Sheridan et al., this volume). The asymmetrical nature of this elongate sediment mound (it is shallower on the northeast rim of the basement trough between Sites 534 and 391) suggests geostrophic current control by the Coriolis force. Bottom currents flowing through this trough, which is formed along an apparent fracture zone, were accelerated and deflected with the entrained muddy bottom water along the right side. There the sediment mound eventually formed as an onlapping deposit. Although this interpretation fits the seismic and drilling observations, it is actualistic in that such occurrences are well documented today. In the modern oceans, bottom currents frequently follow the fracture zone depressions that allow access through the otherwise substantial topographic barrier of the mid-ocean ridge. Sediment-drift ridges and elongate mounds formed along these troughs are also known to occur. Generally the sediment drifts formed by contourite deposits are preferentially deposited on the right side of the fracture zone in the northern hemisphere relative to the direction of bottom flow. The bottom-flow arrows in Figure 11B were accordingly drawn to show a normal clockwise gyre of bottom flow around a bathymetric ridge in the northern hemisphere.

The evidence for bottom-water circulation in Unit 7 corresponds to the increased abundance of the radiolarian silt layers. Generally, the more vigorous circulation in the embryonic Atlantic at that time could have been related to upwelling, which could have increased radiolarian productivity. Indeed, radiolarian cherts are common throughout the Tethyan realm in the Oxfordian, and this event probably signaled the abrupt widening of the Atlantic, the development of more complex surface circulation and divergences, and the resulting upwelling and bottom-water flow.

\section{BLACK SHALE DEPOSITIONAL MODELS AND HYDROCARBON SOURCE POTENTIAL}

A subject of continuing controversy was addressed by drilling at Site 534: that of the origin of the black shales. These interesting sediments were encountered extensively in the Hatteras Formation and the Blake-Bahama Formation, as well as in the newly discovered Jurassic formation, as yet unnamed. Three contrasting explanations on the origin of these shales are included in this volume (Habib; Katz; and Summerhayes and Masran). We review these models, pointing out the salient features of each and stressing their differences.

Katz (this volume) notes that several isolated strata in the Hatteras and Blake-Bahama formations are hydrogen rich and are interpreted to contain significant quantities of autochthonous marine organic matter. In his opinion these occurrences are so restricted in time and space (thickness) that they do not represent major expansions of anoxic bottom-water masses, but rather local and brief, temporary occurrences of such reducing environments. Katz's opinion that the sediments rich in terrestrial organic matter could survive oxidizing depositional environments is accepted by many organic geochemists (Demaison and Moore, 1980; Tissot et al., 1980); however, this does not mean that they could not 


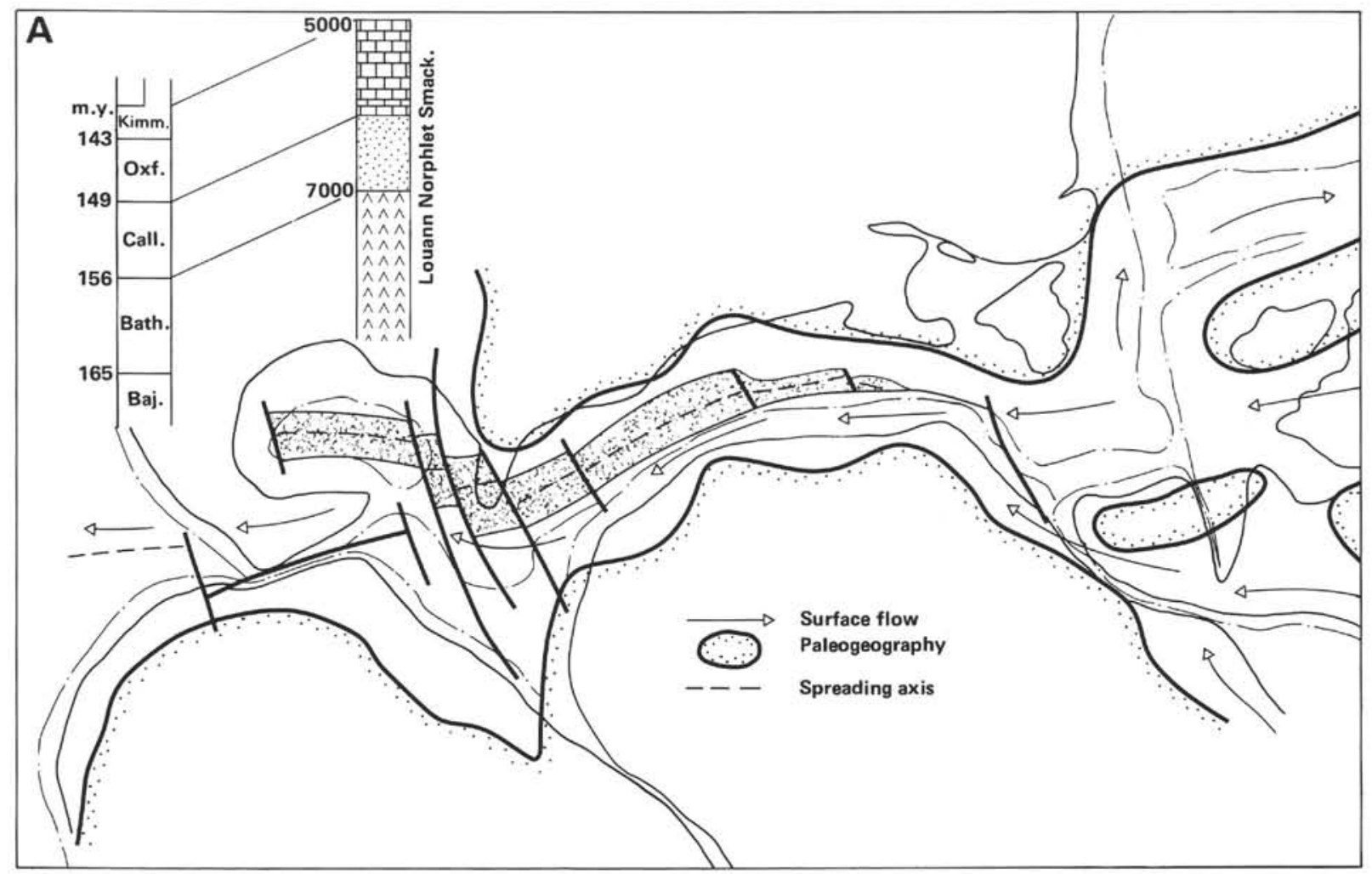

Blake Spur Anomaly time

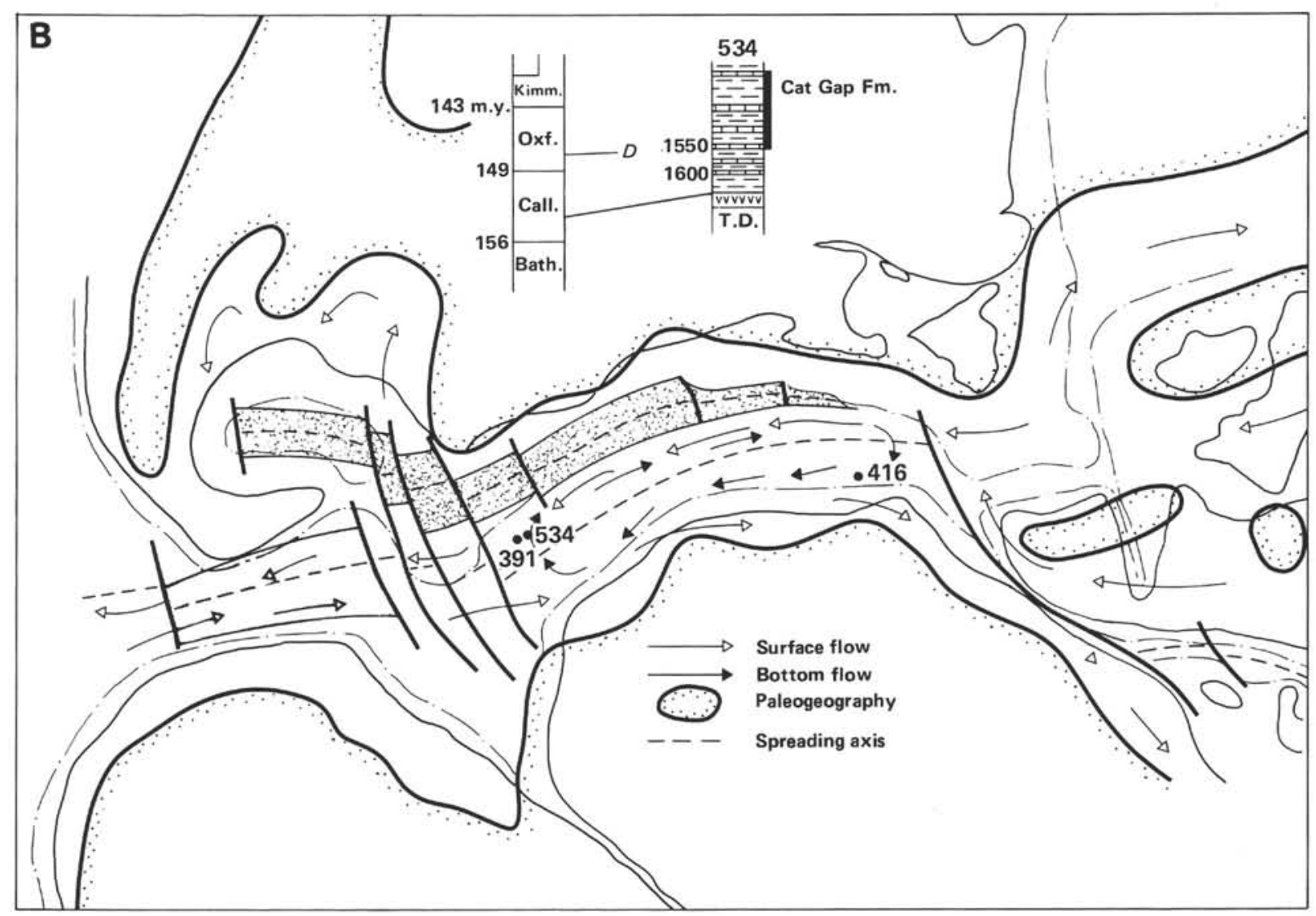

M-26 Anomaly time

Figure 11. A-C. Paleogeography and schematic paleocirculation of the North Atlantic Ocean in the early Callovian (Blake Spur Anomaly), mid-Oxfordian (Anomaly M-26), and early Kimmeridgian (Anomaly M-24). 


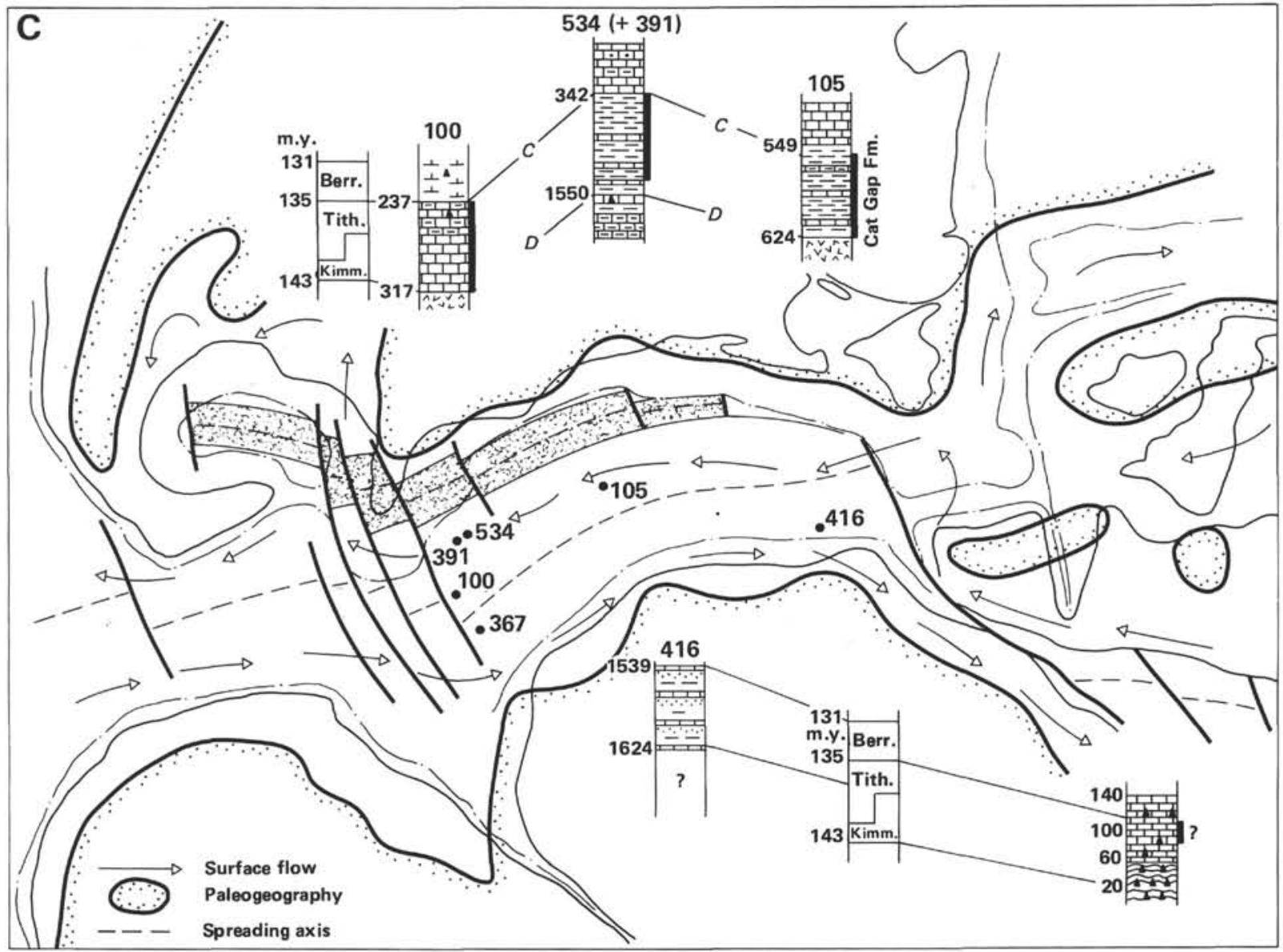

M-24 Anomaly time

Figure 11. (Continued).

have been deposited in reducing environments as well. Other evidence would be needed to reach such a conclusion about the conditions of the bottom water.

Summerhayes and Masran (this volume) have considered this additional evidence by looking at the sedimentologic and age data as well. They conclude that the organic matter reached the Site by turbidity currents or a slow-moving, near-bottom nepheloid layer. They note the particular decrease in abundance of organic matter in the late Aptian versus the great abundance in the Valanginian-Aptian and in the Albian-Cenomanian. Evidence of the well-preserved lamination and lack of biogenic burrowing in these black shales suggest marginal living conditions on the bottom even while there might have been high marine productivity in the surface waters. Summerhayes and Masran feel that there is marine organic matter in these marine shales that required reducing conditions for preservation of both types of organic matter, but that the marine organic matter was diluted at times of increased supply of terrestrial material. Alternations of marine and terrestrial dominance of the organic matter is detected, with higher terrestrial facies in the Valanginian and again in the Aptian-Albian. Citing the Vail et al. (1977) sea-level curve, they conclude that an increase in the supply of terrestrial organics occurred when the sea level dropped, because rivers dumped more terrigenous clastics into the deep basin, and that when the sea level rose there was a dominance of marine organic matter because marine productivity was higher when sea level was high. Regardless of the source of the organic matter, relative abundances, and modes of deposition, these authors feel that reducing bottom water is necessary to explain the preservation of this matter.

Accordingly, Summerhayes and Masran propose a model that involves the influx of oxygen-poor water from the Pacific at times of higher sea level and restriction of the influx during times of lower sea level. With the absence of the supply of oxygen-poor water, the normal circulation of the Atlantic would cause the bottom to become oxidized during times of lower sealevel. Apparently, according to their model, when the Atlantic was restricted it was more oxidizing, but when it was well connected to the Pacific it was reducing (Fig. 12).

In contrast to this model, Habib (this volume) feels that all of the black shales, both with terrestrial and marine organic matter and in all the formations including the Callovian, could have been deposited in the Atlantic with oxidizing bottom-water conditions. He cites evidence in the form of black carbonized organic matter found even in the red shale of the Cat Gap Formation. Habib feels that the presence of this organic matter indi- 

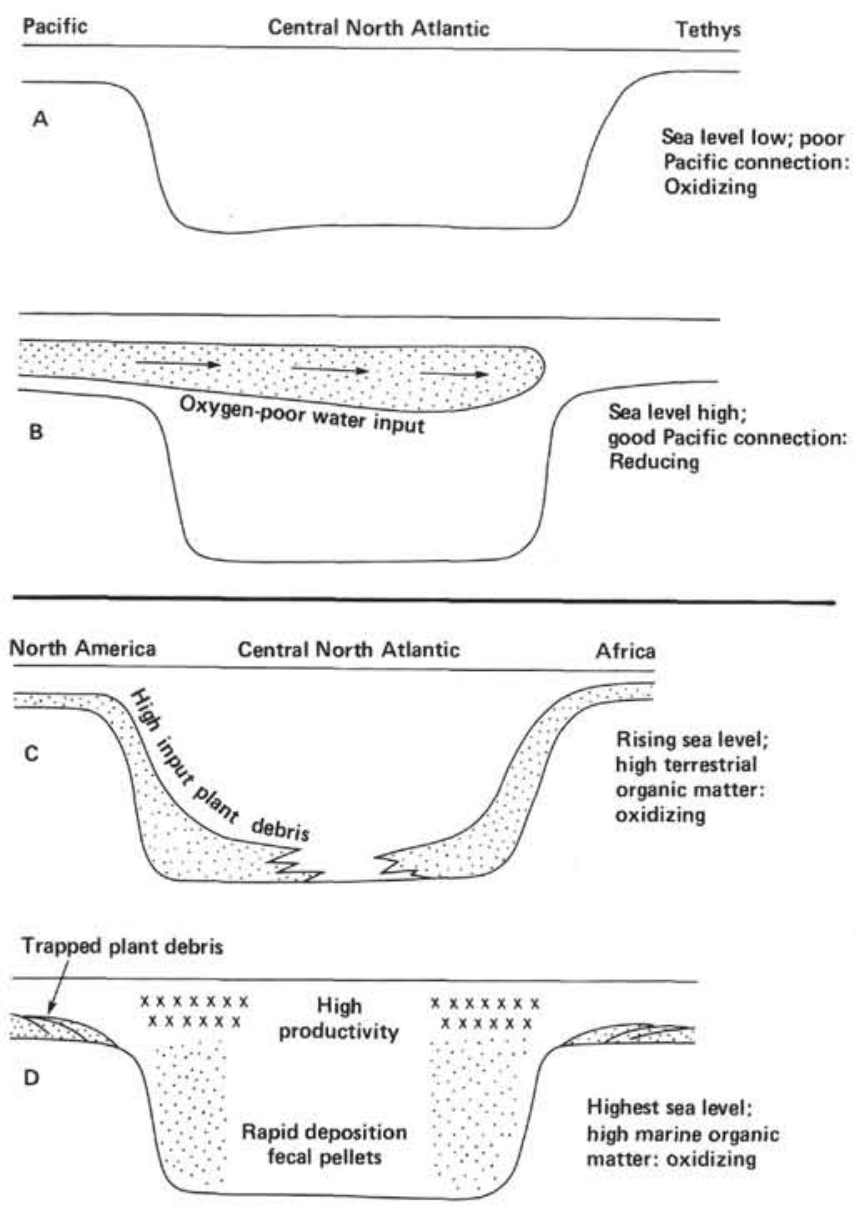

Figure 12. Schematic models for Cretaceous black shale deposition. (A \& B. After Summerhayes and Masran, this volume. C \& D. After Habib, this volume.)

cates that even in the most oxidizing environments and at slow rates of deposition, some organic matter survives. To him, the abundance of preserved organic matter is then a function of the amount and rate of influx (the more rapid the influx the greater the preservation). Habib combines data on the organic microfacies that demonstrate transport sorting and the allochtonous nature of the organic matter with evidence about the stratigraphic age that demonstrates that the kind of organic matter varies with the rate of influx. The influx rate is higher when terrestrial plant material dominates, and it is lower when marine organic matter occurs. Habib also notes the alternations and cycles of occurrences of terrestrial versus marine organic matter dominance.

Whereas Habib admits the preservation of organic sediments below the seafloor will lead to reducing conditions in the sediments, he feels there are cases in the modern oceans where this goes on with the overlying waters being normally oxidized. All that is required is a relatively rapid influx of organic-rich sediments. To explain the preservation of the less resilient marine organic matter, Habib cites evidence that the marine organic matter has microscopic features resembling fecal pellet material. He thus invokes the concept that the marine organic matter is consumed and digested before being rapidly deposited through the oxidizing water masses.

The cyclicity Habib observed between terrestrial versus marine organic facies does correlate in time with the Vail et al. (1977) sea-level curve. During times of rising sea level there is apparently a great influx of terrestrial plant debris (Fig. 12). The greater abundances of the marine microfacies apparently occur during times of highest sea level after the rise. A model to explain this would involve the greater influx of terrigenous material from large coastal rivers during the beginnings of the worldwide sea-level rise, as it affected the continents around the central North Atlantic. As the sea level reached its greatest height, the rivers dropped their terrigenous material, including much plant material, in deltaic estuaries on the continental shelves. At the same time, during the high sea-level stands greater marine productivity occurred, which gave rise to relatively rapid sedimentation of fecal pellet debris.

Habib's model fails to explain the higher-frequency cycles in the black shales manifested in the several-centimeters-thick black and green bands (Site 534 report, this volume). Habib finds similar amounts of organic matter in both the black and green bands, and he concludes that the color is caused by slightly more or less reduced iron. This conclusion implies that the influx of organic matter is not the only control of the sub-bottom Eh (oxidation potential). Rather, some other higher-frequency change, on the order of 20,000 to $100,000 \mathrm{yr}$., must be invoked. Slight global temperature variations due to various astronomic cycles are probably the causes of these cycles in the black shale.

Also, it is difficult to apply Habib's model to explain the occurrences at about the same time in the Jurassic and Cretaceous of black shales at many other places on the earth and in many different types of marine settings (e.g., in the continental interior seaways, which were more like the Baltic Sea of today, and in the distant reaches of the deep Pacific Ocean). Black shales from the Cretaceous Pacific suggest widespread anoxia there, which Summerhayes and Masran (this volume) invoke as a means to reduce the Atlantic. Their model would explain the correlation of Atlantic organic preservation events with those occurring on a global scale. Habib's model, on the other hand, depends only on influx from the local Atlantic borderlands.

However, the organic shale events in the Habib model depend ultimately on global sea level and global surface temperature and humidity, and consequently, they cannot help but correlate in time with other events of organic carbon deposition in many other environments, even if the other carbonaceous deposits might or might not form in truly anoxic environments.

Regarding the petroleum potential of these black shales, they all appear to be thermally immature (Katz, this volume). The terrestrial organic matter would be a good gas and coal source rock, but only a few levels have high yields. The hydrogen-rich marine organic matter has only limited potential to generate liquid hydrocarbons because of its limited extent. 


\section{SEISMIC STRATIGRAPHY AND CORRELATIONS AT SITE 534}

Of importance to the seismic stratigraphy of the western North Atlantic Ocean is the documentation of the age and origin of seismic reflection Horizon D (Sheridan et al., this volume). This was the "new ground" studied as part of Leg 76 and a major objective of the cruise. The correlation of this horizon with the bottomlevelling early Oxfordian limestone turbidites was the successful completion of that objective.

One of the minor revelations was the discovery of Eocene porcellanites occurring as a relatively thin (27-m) unit; this unit is missing at nearby Site 391 , only $22 \mathrm{~km}$ away. The cherts occurring near this interval indicate that the zone of porcellanites and cherts that generally cause seismic Horizon $\mathrm{A}^{\mathrm{c}}$ reaches to Site 534, farther west than heretofore mapped. Because of the thinness of this unit, we interpret that seismic Horizons $\mathrm{A}^{\mathrm{u}}$ and $\mathbf{A}^{\mathrm{c}}$ are merged by convolution interference effects and are seismically irresolvable. This interpretation suggests that there might be more Eocene siliceous deposits existing in the western North Atlantic west of the apparent $\mathrm{A}^{\mathrm{u} / \mathrm{A}^{\mathrm{c}}}$ truncation mapped by Tucholke and Mountain (1979).

There is apparent seismic evidence for possible deepsea unconformities at newly defined seismic reflection Horizons $\beta^{\prime}, C^{\prime}$, and $D^{\prime}$ (Sheridan et al., this volume). Truncations of internal reflections below these horizons, and downlap above are the criteria for erosional and nondepositional hiatuses (Vail et al., 1980). In fact, Vail et al. (1980) identified hiatuses at similar levels on seismic reflection profiles north of Site 534, and those identified in this volume might be the correlative unconformities, although no direct seismic ties have been made to the Vail et al. (1980) profile. Abrupt changes in drilling rate and lithofacies, terminations of fossil zones, and changes in magnetization character are present at depths that correlate well with these seismic unconformities and provide good supportive evidence of their occurrence. However, no biostratigraphic zones are missing, so there is no paleontologic evidence for these new unconformities.

These possible, new unconformities are unlike Horizon $\mathbf{A}^{\mathrm{u}}$ where several stages are missing between the Miocene and Eocene sediments. Also, there must exist a hiatus between the thin unit of Maestrichtian variegated claystones and the deeper Cenomanian black and green claystones, and between the Maestrichtian claystones and the Eocene porcellanites (Fig. 5). These two unconformities, possibly of the mid-Cenomanian or Coniacian, and of the mid-Paleocene, might be correlative to ones of Vail et al. (1980), but they are so close together physically that they are merged into the same event as $\mathrm{A}^{\mathrm{u}}$, the marked unconformity possibly of the Oligocene. Could this be true for the rest of the western Atlantic Ocean as well?

There is no clear indication of seismic Horizon $A^{*}$ at Site 534, which Tucholke and Mountain (1979) correlate with a Maestrichtian chalk layer farther seaward. The merging of all these $\mathbf{A}^{\mathrm{u}}, \mathbf{A}^{\mathrm{c}}$, and $\mathrm{A}^{*}$ reflectors nearer the margin makes the deciphering of the several possible hiatuses difficult. Consequently, it is possible that several erosional events, all of equal importance in terms of material removed, could have occurred from the Cretaceous through the Oligocene. This possibility contrasts with the previously held view that there might have been more continuous deposition in the Late Cretaceous and the Paleogene, and then drastic erosion in the Oligocene.

Disagreements about the correlation of reflectors $\mathrm{C}^{\prime}$, $C$, and $D^{\prime}$ have arisen between Sheridan et al. (this volume) and Shipley (this volume). These differences result from two different approaches applied to make the correlations: one approach uses only certain shipboard velocity measurements and physical properties data (Shipley, this volume); the other approach considers a wider variety of data, including shipboard velocities, limited density logs, drilling rate logs, and geological evidence for hiatuses and physical changes, as well as comparisons with sonobuoy velocities from the site surveys (Site 534 report, this volume; Sheridan et al., this volume). Although the correctness of either of these correlations cannot be uniquely demonstrated, because of the inability to get continuous acoustic and density logs and to create valid synthetic seismograms, there are some points about the correlations that should be pointed out to the reader.

One of the major reasons for the disagreement is the uncertainty about the position of the drill site with respect to the seismic data at the site. Although this uncertainty is less than $1 \mathrm{~km}$, there is enough relief in the reflectors in question (i.e., $\mathrm{C}, \mathrm{C}^{\prime}$, and $\mathrm{D}^{\prime}$ ) that only slight differences in the velocities assumed in the Shipley analysis, and a slight shifting in the possible position of the site, would lead to agreement with the Sheridan et al. (this volume) correlations.

We should state that the uncertainty of less than $1 \mathrm{~km}$ in the position of the site relative to the seismic lines is better accuracy of positioning than any previous DSDP drilling in the western North Atlantic and perhaps anywhere else. The best available Loran $\mathrm{C}$ and satellite navigation was used on the Robert Conrad during the surveys and on the Glomar Challenger during the drilling, and the Loran $\mathrm{C}$ type of navigation is not available in many other parts of the world.

The problem is that even with this relatively excellent positioning, we are trying to discriminate between reflectors in a thin sedimentary section where the mapped horizons are only one wavelet apart. Thus, calculated time differences of only $0.04 \mathrm{~s}$ could shift the correlations by one wavelet. Uncertainties in the calculated times to reflectors using assumed velocities, as Shipley has done (this volume), are very sensitive to uncertainties in those velocities.

For example, by increasing the assumed velocity in the $A^{u}-\beta^{\prime}$ interval in the Shipley acoustic model by only $7 \%$ and by shifting the possible location of the site by less than $1 \mathrm{~km}$, there can be achieved good correlation of the $C^{\prime}, C$, and $D^{\prime}$ reflectors in agreement with that of Sheridan et al. (this volume). This $A^{u}-\beta^{\prime}$ interval is quite critical, for in this interval the Shipley (this vol- 
ume) model assumes a velocity of $1.86 \mathrm{~km} / \mathrm{s}$, which is quite a bit lower than the $2.50 \mathrm{~km} / \mathrm{s}$ velocity Bryan et al. (1980) reports from the same interval based on sonobuoy data. There are reasons to expect that the sonobuoy values are too high (Site 534 report, this volume), but the $1.86 \mathrm{~km} / \mathrm{s}$ velocity of Shipley (this volume) is unusually low for this depth of burial. Apparently, these $1.86 \mathrm{~km} / \mathrm{s}$ velocities are the same as the averaged values of those measurements made in the laboratory on board the Challenger. No decompaction corrections were applied by Shipley (this volume) for these measurements. This might be the source of the problem.

We note also that Shipley's correlation of $\mathrm{C}^{\prime}$ and $\mathrm{C}$ places them at depths where the good density log does not indicate a drastic physical properties contrast. This is probably because Shipley accepted the boundaries of the sedimentologic units as the boundaries of his acoustic units. Often, however, the sedimentologic boundaries are based on the changes in composition, and the percent of $\mathrm{CaCO}_{3}$ rather than on whether that $\mathrm{CaCO}_{3}$ is poorly cemented or strongly consolidated, which is the property that causes an impedance contrast. This is possibly true of the boundary of Lithologic Subunits 5c and $5 \mathrm{~d}$ at $1268 \mathrm{~m}$, which Shipley correlates with Horizon $\mathrm{C}$. The gamma logs and drilling rate changes suggest that the physical break is shallower, at approximately $1250 \mathrm{~m}$. At this sub-bottom depth the nannofossil chalks become harder and cemented to form a massive unit, and the clay content has decreased enough to decrease the gross fissility of the rocks. In certain cases the physical contrast is not exactly at the boundary of the sedimentologic unit defined on other grounds. Most of the time these are the same or are reasonably close in depth.

Shipley accepted the sedimentologic divisions in an attempt to avoid more subjective reasoning. One of his goals was to achieve a more objective means to establish seismic correlations using only the physical properties measurements. However, accepting the sedimentologic unit boundaries, while objective on his part, just involves the transferral of subjective decisions made by others. This does not make the final correlation any more correct.

\section{ORIGIN OF THE GREAT ABACO MIOCENE MASS FLOW DEPOSITS AND THE ELEUTHERA FAN COMPLEX}

New information from seismic reflection profiles in the area of Site 534 might clarify the presence of the massive, proximal turbidites, grain flows, and debris flows deposited during the Miocene. Because the site is in the center of the Blake-Bahama Basin, more than 200 $\mathrm{km}$ from the nearest possible sediment source (the Blake Plateau) and the nearest possible canyons (Great Abaco and Grand Bahama canyons), and the facies are so coarse, it is hard to imagine a sheet flow of this sediment spreading out over the entire basin from a point source. This is especially true of individual coarse flows that are at least as thick as $10 \mathrm{~m}$, and might be as thick as $30 \mathrm{~m}$.
The synthesis of the seismic reflection profiles available (Sheridan et al., this volume; Sheridan et al., 1981; and Sheridan, this volume) allows the mapping of a buried Miocene ridge that creates a drastic, hummocky hyperbolic reflection unit. This ridge occurs just west of Site 534 and can be traced to the bight in the Blake-Bahama Escarpment where Great Abaco and Grand Bahama canyons enter the Blake-Bahama Basin from the Bahamas.

The interpretation is now made that this buried ridge, called Eleuthera Ridge, is a deep-sea fan complex (Bliefnick et al., this volume). The hummocky seismic pattern is thought to be created by small-scale channels and levees that crisscross the fan in a complicated distributary pattern. The confinement of an individual turbidite, debris flow, or grain flow in these narrow pathways of the channels allows far greater velocities, and the capacity of the flows therefore varies far from their source. A flow debouching from one of these fan channels could then come from a point source only a few tens of kilometers distant from Site 534, which could explain the very proximal facies found in the Miocene Great Abaco Member.

\section{GAS HYDRATES ON THE BLAKE OUTER RIDGE}

Great strides have been in understanding gas hydrates in the marine environment as a result of drilling at Site 533. Prior to drilling this hole the hydrate presence was based on theoretical considerations, the observed acoustic properties, and conformity to geochemical principles. Now, actual gas hydrates have been seen in the cores at Site 533, and various experiments, including the first successful deployment of the Pressure Core Barrel (PCB), measured geochemical parameters that give strong evidence of hydrates. The most important of these is the measurements of gas volume and composition of the recovered pieces of gas hydrate. These measurements indicate a gas volume of 20 times the normal pore volume present in the sample, requiring much more gas than could be present in normally saturated pore fluid (Kvenvolden, this volume). Sublimation of solid gas hydrate must explain these large gas volumes. The composition of the gas involved in the hydrate is mostly methane, and no hydrocarbons of larger size than isobutane were found. This last factor agrees with the theory about the size relationship of the gas hydrate crystal structure (Kvenvolden, this volume).

Pressure decline curves on two of the four PCB retrievals had sawtooth patterns that indicate the presence of small amounts of gas hydrates (Brooks et al., this volume). Apparently, the sublimating hydrate contributed gas pressures to merge with the normal, background degassing of the core material in the PCB. The merged volumes then caused the repeated pressure buildup with time after each venting. Quantitative estimates of the portion of the pore volume in gas hydrate form could not be gained from these PCB experiments, but the acoustic velocities of the hydrated sediments measured by sonobuoys, and the decrease in salinity of the pore water in hydrated cores suggest that 10 to $30 \%$ of 
the bulk sediment pore space is hydrated (Site 533, report this volume). The physical distribution of the hydrates, either as thin interstratified solid layers or as small crystals at contacts of the mineral grains more homogeneously distributed in all the pore spaces, is uncertain from the work at Site 533 .

Isotopic studies of the gases trapped from the sublimating hydrates indicate that little fractionation in composition occurred as the gas hydrates decomposed (Brooks et al., this volume). The $\mathrm{C}^{13}$ isotopes and the $\mathrm{C}_{1} / \mathrm{C}_{2}$ ratios down the hole indicate that there was normal diagenesis of biogenic organic matter within the sediments, and that this was the source of the gas trapped in the hydrate form (Galimov and Kvenvolden, this volume). No indication of thermogenic gas was found.

Other isotopic studies of the gases from Site 533 (Claypool and Threlkeld, this volume) reach negative conclusions contradicting the evidence for the existence of gas hydrates at the Site. These authors indicate that theoretical calculations imply that not enough methane was generated in the sediments to form stabilized gas hydrate, which requires more methane than normally would saturate the pore fluids. The calculations might be incorrect or the excess methane generation is nonuniform in distribution. This latter possibility agrees with other indications that the sediments above the BSR are only partially hydrated (10 to $30 \%$ ). Partially hydrated sediments could indicate that the methane present is not from a source deeply buried under the continental rise sediments, and this fact has implications for the petroleum potential of these thick sediments. Also, the possibly heterogeneous distribution of the gas hydrates in the layer above the bottom simulating reflector leads to the conclusion that the gas hydrates would not be a good source of commerical gas in themselves, and would not perform well as sealants for gas accumulating below the BSR (Kvenvolden, this volume). However, Dillon et al. (1980) have identified amplitude anomalies, bright spots, beneath the BSR where there is possible structural closure and gas could accumulate. In these cases, the BSR seems to act as a sealant, which disagrees with the conclusion of Kvenvolden (this volume).

\section{HEAT FLOW IN THE BLAKE-BAHAMA BASIN}

Downhole temperatures at Sites 533 and 534 were measured at much greater depths than any previous data on this part of the margin. At Site 533, very good measurements to sub-bottom depths of $400 \mathrm{~m}$ yield a welldocumented thermal gradient of $3.6^{\circ} \mathrm{C} / 100 \mathrm{~m}$ near the bottom of the hole (Site 533 report, this volume). Using the average value of conductivity for Site 533 of 3.38 $\mathrm{mcal} / \mathrm{cm}^{\circ} \mathrm{C}$ s (Site 533 report, this volume) yields a heat flow of $1.22 \mathrm{HFU}$.

For Site 534 the temperature measurements were quite disturbed by the cooler drilling fluids, and conductivity measurements were only sporadically available. As an exercise, Henderson and Davis (this volume) attempt to allow for drilling disturbance of Hole 534A and arrive at a minimum estimate of $30^{\circ} \mathrm{C} / 100 \mathrm{~m}$ and a maximum estimate of $41^{\circ} \mathrm{C} / 100 \mathrm{~m}$ for the thermal gra- dient in the hole. Also, using the few conductivity measurements available for Hole 534A, and relating these to the more numerous measurements of porosity, they determine an algorithm between porosity and conductivity that appears reasonable. Based on this porosity-conductivity relationship, they establish an estimated conductivity of $3.35 \mathrm{mcal} / \mathrm{cm}^{\circ} \mathrm{C}$ s. Henderson and Davis (this volume) note that the resulting range in heat flow values, 1.01 to $1.37 \mathrm{HFU}$, agrees with nearby piston core measurements made from the Knorr. We note here that their estimates are also very close to the $1.22 \mathrm{HFU}$ value determined with much better data from Site 533 . Henderson and Davis (this volume) conclude, therefore, that their techniques of estimation might be useful in application to other DSDP holes where the temperature and conductivities are only poorly known. We agree.

These heat flow values determined from Sites 533 and 534 are typical for this part of the western Atlantic Ocean. This is the first time such determinations were made to such great depths below the seafloor, and it is important to note that these data conform closely to other measurements made by the shallow piston-coring techniques.

Finding normal heat flow values in this area of the Jurassic Magnetic Quiet Zone supports the other conclusions made in this volume, namely that the Outer Magnetic Quiet Zone is composed of normal oceanic crust. The character of the basalt cored at Site 534 indicates this fact, and the subsidence history of Site 534 also appears normal.

\section{CONTOURITE FORMATION OF THE BLAKE OUTER RIDGE}

The results of Site 533 added important information on the processes and timing of the formation of the Blake Outer Ridge. The seismicly identified unconformity at a depth of approximately $158 \mathrm{~m}$ is correlated with an abrupt change in shear strength (Site 533 report, this volume). Also, there is good evidence that the latest Pliocene biostratigraphic zones are thinner than the adjacent older and younger ones, suggesting some condensation or hiatuses (Moullade, this volume). Although no zones are actually missing, the abrupt and unusual sedimentation rate change at the base of the Pleistocene could also be interpreted as a hiatus.

The seismic reflection profiles across this unconformity show angular truncation of the underlying beds, as if significant erosion has taken place. Also, the overlying Pleistocene sediments have downlapping and mud wave seismic bed forms, which suggest current deposition. The downlaps at the drill site suggest a period of nondeposition as well after the erosional surface formed.

Physical stratification in the rather homogeneous, green muds of Site 533 reveal little of the structure at the unconformity. This was a particular failing of the sediments at the site where the seismic profiles reveal what appear to be marked current stratification. The Blake Outer Ridge has long been thought to have formed by the accretion of hemipelagic mud deposited from nepheloid layers carried by contour currents (Heezen et al., 1966). Seismic documentation of this process seems con- 
vincing. Unfortunately the cores give no obvious visual (certainly not the "ubiquitous" stratification) evidence expected of contourites. Some occurrences of fissility in the muds and claystones might reflect bedding structures, and there is some coloration differences in the Pleistocene deposits, but little else is observed. Perhaps $\mathrm{X}$-ray studies could reveal hidden structures in the finegrained muds and claystones.

Other supporting evidence of the unconformity at Site 533 is the mineralogy study of Matsumoto (this volume). He notes that the sediments below the unconformity are rich in Fe and $\mathrm{Mn}$ (Zone III) and that this is not a diagenetic effect. The sediments were originally rich in these elements. Above the unconformity in the Pleistocene sediments, there are a dolomite-rich (Zone I) layer and a siderite-rich (Zone II) layer. Comparison with nearby Sites 102 and 103 on the crest of the Blake Outer Ridge south of Site 533 reveals that the dolomite layer and most of the siderite layer are missing. This leads Matsumoto (this volume) to conclude that deep submarine erosion in the Pleistocene was also a major contributor to the form of the Blake Outer Ridge, in addition to the accretion of the hemipelagic mud.

\section{RECOMMENDATIONS FOR FUTURE DRILLING AND RESEARCH}

This synthesis, the review in the Introduction to this volume, and the specialty chapters leave many questions unanswered. Other questions are generated because the results of Sites 533 and 534 in the western North Atlantic Ocean are definite, and the implications of these results conflict with existing hypotheses. One such example is the dating of the Blake Spur Marine Magnetic Anomaly and the implications for the timing of later breakup of the eastern North American margin and the Gulf of Mexico. Another is the evidence for sediment starvation, rather than erosion, as the principal cause of the widespread Cenomanian-Miocene hiatus in the Blake-Bahama Basin.

Consequently, the results of drilling at DSDP Sites 533 and 534 have identified a number of key research topics that should be addressed to further our understanding and better economic use of the geology of the eastern North American continental margin, and to develop better geochemical, sedimentological, paleontological-stratigraphical, and geophysical models in paleoceanography.

(1) Hole $534 \mathrm{~A}$ is the first DSDP hole to reach basement well inside the Jurassic margin Magnetic Quiet Zone; further drilling in the outer marine Jurassic Magnetic Quiet Zone should be done to document its age of Callovian-Oxfordian. Such drilling will strengthen the estimate of relatively fast $(\sim 3 \mathrm{~cm} / \mathrm{yr}$.) early Atlantic spreading, which, in conjunction with revisions of Jurassic paleomagnetic and biochronostratigraphy as presented in this volume, details early paleoceanographic history. The age of the quiet zones should also be tested by drilling the basement in the Pacific Jurassic Quiet Zone.

We are aware that these suggestions are presently in the program for future deep-sea drilling, but no one can be sure that the planned drilling will be successfully completed or even started. Reiteration here of these proposals is therefore warranted.

(2) The small amplitude lineation M-28, as modelled in the marine Jurassic Magnetic Quiet Zone, has not been substantiated by drilling. The basalt at the bottom of Hole 534A was normal in its polarity of remanent magnetization, rather than reversed. It is thought that the Jurassic Magnetic Quiet Zone is an extended period of normal polarity, with possible short reversal events or intensity fluctuations as the cause of the weak lineations. The basalt at Site 534 that is near the eastern boundary of M-28 could be a pillow flow, generated just a few kilometers from the Site during the time of the next younger normal polarity. These normally magnetized flows could then have laid on top of the reversely magnetized flows deposited a short time before in the Anomaly M-28 zone.

Often at DSDP sites in the past drilling has penetrated the basalt pillow lavas of alternating polarities even though they are located on well-defined seafloor magnetic anomalies. Such interlayering of alternating polarity basalts will produce no seafloor magnetic anomalies measured at the surface, and this seems to imply that the source of the seafloor magnetic anomalies are deeper, perhaps in the dike layer $(2 \mathrm{~b})$ below the pillow basalts (2a). A possible solution to this problem of the weak lineation will require a combined approach of further shipborne magnetic studies of the linear anomalies, documentation in the Oxfordian-Callovian section on land of these past field variations, either of reversals or intensity variations, and deeper drilling into layers $2 \mathrm{a}$ and $2 \mathrm{~b}$ at more than one location on a wellmapped weak lineation.

(3) The Jurassic biochronology and magnetochronology that can be applied to Tethyan (and boreal) ocean sites is still relatively undeveloped. Site 534 did not yield good paleomagnetic data for part of the Jurassic section, in part because of poor sediment recovery. The same is true for the biostratigraphy, which shows controversy on the position of the Oxfordian/Kimmeridgian and Kimmeridgian/Tithonian boundaries (Gradstein, this volume; and the section on Jurassic time scale in this chapter). Some of the necessary studies are being carried out in Tethyan and boreal land-based sections, but, particularly in the case of foraminifers, nannofossils, and palynomorphs, unique oceanic zonations have to be developed and properly calibrated to ammonite and calpionellid standard zonations in land sections. The Jurassic magnetic reversal scale as shown in Figure 5 is still untested for all but a few reversals in the early Keathley Sequence in deep-sea sites on seafloor magnetic anomalies. It is essential that further drilling take place to verify and strengthen the Jurassic time scale (see the section on Jurassic time scale in this chapter).

(4) Undisputed dating of the outer marine Jurassic Magnetic quiet zone between M-25 and the Blake Spur Anomaly brings into question the age and nature of the inner Jurassic Quiet Zone between the Blake Spur and the East Coast magnetic anomalies. Previously this corridor was thought to be Jurassic oceanic crust, possibly 
as old as the Pliensbachian. Now, however, the results at Site 534, yielding higher spreading rates and extrapolation of these into the ECMA/BSMA corridor, indicate that the inner Magnetic Quiet Zone might be upper Bathonian oceanic crust. This would conform to new knowledge of the paleomagnetic time scale, including possible lower Bathonian reversals, and of the age of the Gulf of Mexico, a possible continuation of the ECMA/ BSMA corridor. Future drilling in the ECMA/BSMA corridor could address this controversy about the character and age of basement. Recently a basement knoll was found in seismic surveys of the inner Magnetic Quiet Zone off New Jersey. The knoll appears to have been in place in the Jurassic, based on the onlap of the Jurassic seismic reflectors (J. I. Ewing, personal communication, 1981). Could this be a Jurassic seamount with a possible Bathonian reef on top? If so, drilling into this knoll, which is within reach of the Challenger drill string, would give some knowledge of the age of basement and subsidence history of the oldest oceanic crust, if indeed it is oceanic. Although the seismic refraction and other geophysical data in the inner Quiet Zone appear compatible with an oceanic origin, it is still possible that a thin transitional crust might exist there.

(5) Prior to drilling at Site 534, only seismostratigraphic data existed with which to identify the paleoenvironment of the Middle Jurassic oceans. Site 534 revealed Callovian-Oxfordian variegated and dark shale, radiolarite and limestone turbidite sediments of bathyalabyssal depth, and evidence of contourites and Tethyan surface water exchange. Still, our knowledge of the Middle Jurassic oceans using one data point is scant. Questions remain on the local or ocean-wide extent and nature of bottom currents, and the exact extent of surface water exchange with Tethys and the Pacific in particular, using updated biogeographic and paleogeographic reconstructions. Isotope studies should help characterize Jurassic water-mass properties and distributions in time and space and may help to explain the remarkable affinity in composition of Jurassic benthic foraminiferal assemblages at Site 534 and at Site 261, Indian Ocean (Gradstein, this volume). Evidence for paleobathymetric change at ocean sites as Sites 534 largely derives from backtracking. Independent evidence for the depth of the Jurassic oceans should be sought that will aid in delineation of the lysocline and the hypsometric curve.

The recalculation of Jurassic spreading rates with a tendency to higher values than previously thought should lead to a reassessment of early ocean history and its implications for global transgression in the Callovian.

(6) A single drill site in the Middle Jurassic ocean does not allow establishment of regional Jurassic abyssal lithostratigraphy and seismostratigraphy. For example, Ogg et al. (this volume) discuss the problems in defining the lower boundary of the Cat Gap Formation, because of the different lithofacies in the lowermost cores of Hole 534A. How unique is this lithofacies and how does it relate to its eastern Atlantic counterpart inferred from a seismic Horizon D equivalent (K. Hinz, personal communication, 1981)?
(7) Controversy over the correlation of the seismic profiles and physical properties-lithology at Site 534 by Shipley (this volume) versus Sheridan et al. (this volume) can be resolved by deeper drilling into the reflectors $C\left(\mathrm{~J}_{1}\right), D\left(\mathrm{~J}_{2}\right)$, and $\mathrm{J}_{3}$ (untested) at a place where they are not condensed in a profile only one wavelet apart. Good density and acoustic logs, run continuously through the Jurassic sediments as at Site 534, are also needed. More detailed, calibrated seismostratigraphy will help in better mapping the paleoenvironment of the Jurassic ocean.

(8) As discussed here (see the section on Late Cretaceous to Paleogene deposition and erosion) and in the Site 534 report, the extent of abyssal sedimentation and erosion over an $80-\mathrm{m} . \mathrm{y}$. period in the Cenomanian through the Oligocene is still largely unknown (see also Rovertson, this volume). The evidence at Site 534 favors starvation rather than erosion, but both processes may have been active. Stratigraphic correlations in this interval in several Atlantic, Indian, and Pacific ocean sites are questionable and need refinement through better recovery of condensed sections (as at Site 534) and a more detailed study of the cores, particularly geochemically and stratigraphically. Such studies will help to address the reasons for and extent of this prolonged sediment starvation in the deepest part of the basin, and assess below CCD dissolution as a means of balancing surface waters productivity at that time.

(9) Uncertainty remains on the origin, amount, and extent of the gas hydrates encountered at Site 533 on the Blake Outer Ridge (Claypool et al., this volume; Kvenvolden et al., this volume). What is the precise volumetric percentage of the gas hydrate, and is microcrystalline dissemination in tiny pore spaces realistic? To what extent is this gas hydrate a seal for gas mapped in a bright spot below the gas hydrate bottom-simulating reflector on the Blake Outer Ridge (Dillon et al., 1980)?

Further testing through deeper drilling in the gas hydrate clays is desirable, in conjunction with further acoustic and physical properties mapping. Good acoustic, density, and resistivity logs must be taken in the hydrated sediments to measure in situ physical parameters.

(10) The Blake Outer Ridge has long been considered the classic sediment drift deposit of enormous size (see Site 533 report, this volume). Seismicially the Ridge appears as a contourite-built feature, but the detailed coring at Site 533 failed to produce the expected stratification. The definition of contourites involving ubiquitous laminations appears inapplicable at Site 533 and calls for further investigation, which should involve X-ray studies, magneto stratigraphy, and isotope stratigraphy to infer sediment transport drift and nepheloid layering. Analog and digital modelling of drifts the size of the Blake Outer Ridge may clarify the nature of this enormous sedimentary feature.

In this chapter we have emphasized the extraordinary accomplishments of Deep Sea Drilling Project Leg 76, after only a decade of Atlantic Ocean drilling. Yet these accomplishments will wither on the tree of cultural and economic growth and accomplishment if not followed up by further testing and exploration. In this sense Leg 
76 is typical of all successful scientific research. New answers breed new questions to challenge and enlighten our and the next generation of mankind.

\section{ACKNOWLEDGMENTS}

J. Hall (Dalhousie University, Halifax, N. S.) critized a version of this manuscript; Carol Mitchell and G. Cook (Bedford Institute of Oceanography, Dartmouth, N. S.) provided typing and drafting services. We thank them for their support.

\section{REFERENCES}

Ager, D. V., 1975. The Jurassic World Ocean (with special reference to the North Atlantic). In Proc. Jurassic Northern North Sea Symposium, Stavanger. Norwegian Petrol. Soc., pp. 1-43.

Arkell, W. J., 1956. Jurassic Geology of the World: New York (Hafner Publishing Co.).

Armstrong, R. L., 1978. Pre-Cenozoic Phanerozoic time scalecomputer file of critical dates and consequences of new and in-progress decay-constant revisions. In Cohee, G. V., Glaessner, M. F., and Hedberg, H. D. (Eds.), The Geological Time Scale. Am. Assoc. Pet. Geol. Stud. Geol., 6:73-91.

Ascoli, P., 1977. Foraminiferal and ostracod biostratigraphy of the Mesozoic-Cenozoic, Scotian Shelf, Altantic Canada. First Int. Symp. Benthonic Foraminifer Pt. B, Halifax, 1975. Maritime Sed. Spec. Publ., 1:653-771.

Barr, K. W., 1974. The Caribbean and plate tectonics-some aspects of the problem. Verh. Naturforsch. Ges. Basel, 84(1):45-67.

Benson, W. E., Sheridan, R. E., et al., 1978. Init. Repts. DSDP, 44: Washington (U.S. Govt. Printing Office).

Bryan, G. M., Markl, R. G., and Sheridan, R. E., 1980. IPOD site surveys in the Blake-Bahama Basin. Mar. Geol., 35:43-63.

Bujak, J. P., and Williams, G. L., 1977. Jurassic palynostratigraphy of offshore eastern Canada. Proc. Symp. Strat. Micropal. Atlantic Basins and Borderlands, Delaware 1976, New York (Elsevier), pp. 321-329.

Cardozo, J. N., Wardroper, A. M. K., Watts, C. D., Barnes, P. J., Maxwell, J. R., et al., 1978. Preliminary organic geochemical analyses; Site 391, Leg 44 of the Deep Sea Drilling Project. In Benson, W. E., Sheridan, R. E., et al., Init. Repts. DSDP, 44: Washington (U.S. Govt. Printing Office), 617-624.

Channell, J. E. T., Ogg, J. C. and Lowrie, W., in press. Geomagnetic polarity in the Early Cretaceous and Jurassic. Phil. Trans. R. Soc. London.

Copestake, P., and Johnson, B., 1981. Lower Jurassic (HettangianToarcian) Foraminifera from the Mochras borehole, North Wales; systematic and biostratigraphical micropaleontology. Rept. Inst. Geol. Sciences, U.K., 1-162.

Demaison, G. J., and Moore, G. T., 1980. Anoxic environments and oil source bed genesis. Am. Assoc. Pet. Geol. Mem., 64: 1179-1209.

Deroo, G., Herbin, J. P., Roucaché, J. R., Tissot, B., Albrecht, P., et al., 1978. Organic geochemistry of some Cretaceous claystones from Site 391, Leg 44, western North Atlantic. In Benson, W. E., Sheridan, R. E., et al., Init. Repts. DSDP, 44: Washington (U.S. Govt. Printing Office), 593-598.

Dillon, W. P., Grow, J. A., and Paull, C. K., 1980. Unconventional gas hydrate seals may trap gas off Southeast U.S. Oil \& Gas J., 87(1):124-130.

Doeven, P. H., in press. Cretaceous nannofossil stratigraphy and paleoecology of the Northwestern Atlantic. Bull. Geol. Surv. Canada.

Doeven, P. H., Gradstein, F. M., Jackson, A., Agterberg, F. P. and Nel, L. D., 1982. A quantitative nannofossil range chart. Micropaleontology, 28(1):85-92.

Dow, W. G., 1978, Geochemical analyses of samples from Holes $391 \mathrm{~A}$ and 391C, Leg 44, Blake-Bahama Basin, In Benson, W. E., Sheridan, R. E., et al., Init. Repts. DSDP, 44: Washington (U.S. Govt. Printing Office), 625-634.

Drushtchitz, V. V., and Gorbatschik, T. N., 1979. Zonengliederung der Unteren Kreide der sudlichen Ud SSR nach Ammoniten und Foraminiferen. Aspekte der Kreide Europas. Int. Union Geol. Sci. Ser. A, 6:107-116.
Exton, J., and Gradstein, F. M., in press. Early Jurassic stratigraphy and micropalaeontology of the Grand Banks and Portugal. In G. Westermann (Ed.), Jurassic and Cretaceous Biochronology and Biogeography of North America. Mem. Geol. Assoc. Canada.

Geological Society of London, 1964. Geological Society Phaenerozoic time-scale. In The Phaenerozoic Time-Scale. Geol. Soc. London Quart. J., 120:260-262.

Gradstein, F. M., 1977. Biostratigraphy and biogeography of Jurassic Grand Banks Foraminifera. First Int. Symp. Benthonic Foraminifera, Pt. B, Halifax, 1975. Maritime Sed. Spec. Publ., 1: 557-583.

1978. Biostratigraphy of Lower Cretaceous Blake Nose and Blake-Bahama Basin Foraminifers, DSDP Leg 44, western North Atlantic Ocean. In Benson, W. E., Sheridan, R. E., et al., Init. Repts. DSDP, 44: Washington (U.S. Govt. Printing Office), 663-701.

Gradstein, F. M., Bukry, D., Habib, D., Renz. O., Roth, P. H., Schmidt, R. R., Weaver, F. M., and Wind, F. H., 1978. Biostratigraphic summary of DSDP Leg 44-northwestern Atlantic Ocean. In Benson, W. E., Sheridan, R. E., et al., Init. Repts. DSDP, 44: Washington (U.S. Govt. Printing Office), 657-662.

Gradstein, F. M., Williams, G. L., Jenkins, W. A. M., and Ascoli, P., 1975. Mesozoic and Cenozoic stratigraphy of the Atlantic continental margin, eastern Canada. Can. Soc. Pet. Geol. Mem., 4: 103-131.

Habib, D., and Knapp, S. D., 1982. Stratigraphic utility of Cretaceous small acritarchs. Micropaleontology, 28(4):335-372.

Hallam, A., 1975. Jurassic Environments: London (Cambridge University Press).

Heezen, B. C., Hollister, C. D., and Ruddiman, W. F., 1966. Shaping of the continental rise by deep geostrophic contour currents. Science, 152:502-508.

Hollister, C. D., Ewing, J. I., et al., 1972. Init. Repts. DSDP, 11: Washington (U.S. Govt. Printing Office).

Jaffrezo, M., 1980. Les formations carbonateés des Corbières (France) du Dogger à L'Aptien. Micropaleontologie stratigraphique, biozonation, paléoécologie. Extension des resultats à la Mésogée [Ph.D. dissert.]. Université Pierre et Marie Curie.

Jansa, L., Enos, P., Tucholke, B. E., Gradstein, F. M., and Sheridan, R. E., 1979. Mesozoic and Cenozoic sedimentary formations of the North American Basin; western North Atlantic. In Talwani, M., Hay, W., and Ryan, W. B. F. (Eds.), Deep Sea Drilling Results in the Atlantic Ocean: Continental Margins and Paleoenvironment. Am. Geophys. Union, Maurice Ewing Series, 3:1-57.

Klitgord, K. D., and Grow, J. A., 1980. Jurassic seismic stratigraphy and basement structure of the western Atlantic Quiet Zone. Am. Assoc. Pet. Geol. Bull., 64:1658-1680.

Kourdell, M. Maldonado (Ed.), 1956. Estratigrafia y Paleontologia del Jurasico Inferior y Medio Marino de la Region Central de la Sierra Madre Oriental, Mexico. 20th Congr. Geol. Int., Mexico 1956, Excursion C-8.

Lancelot, Y., Seibold, E., et al., 1978. Init. Repts. DSDP, 41: Washington (U.S. Govt. Printing Office).

Lancelot, Y., and Winterer, E. L., 1980. Evolution of the Moroccan Oceanic Basin and adjacent continental margin-a synthesis. In Lancelot, Y., Winterer, E. L., et al., Init. Repts. DSDP, 50: Washington (U.S. Govt. Printing Office), 801-823.

Lowrie, W., Channell, J. E. T., and Alvarez, W., 1980. A review of magnetic stratigraphic investigations in Cretaceous pelagic carbonate rocks. J. Geophys. Res., 85:3597-3605.

Moullade, M., 1966. Etude stratigraphique et micropaleontologique du Cretacé inferieur de la "Fosse Vocontienne", Doc. Lab. Geol. Fac. Sci. Lyon, 15 (fasc. 1, 2):1-369.

Ogg, J., 1980. Upper Jurassic magnetostratigraphy from Northern Italy. EOS, Trans. Am. Geophys. Union, 61:216.

Ogg, J. G., Channell, J. E. T., Winterer, E. L., and Baumgartner, P. O., 1981. Magnetostratigraphy of Oxfordian and Kimmeridgian cherts and siliceous limestones of northern Italy. Int. Assoc. Geomagn. Aeron., 4th Scientific Assembly, Edinburgh, Scotland, pp. 209-210. (Abstract and Program)

Remane, J., 1978. Calpionellids. In Haq, B. U., and Boersma, A. (Eds.), Introduction to Marine Micropaleontology: New York (Elsevier), pp. 161-170. 
Renz, O., Imlay, R., Lancelot, Y., and Ryan, W. B. F., 1975. Ammonite-rich Oxfordian limestones from the base of the continental slope off Northwestern Africa. Eclogae Geol. Helv., 68(2):431-448.

Roth, P. H., 1978. Cretaceous nannoplankton biostratigraphy and oceanography of the northwestern Atlantic Ocean. In Benson, W. E., Sheridan, R. E., et al., Init. Repts. DSDP, 44: Washington (U.S. Govt. Printing Office), 731-761.

Salvador, A., and Green, A. R,. 1980. Opening of the Caribbean Tethys (origin and development of the Caribbean and Gulf of Mexico). Colloque C5, Geology of the Alpine Chains Born of the Tethys. Mem. BRGM, 115:224-229.

Sheridan, R. E., Crosby, J. T., Bryan, G. M., and Stoffa, P. L., 1981. Stratigraphy and structure of the southern Blake Plateau, northern Florida Straits, and northern Bahama Platform. Am. Assoc. Pet. Geol. Bull., 65:2571-2593.

Sheridan, R. E., Pastouret, L., and Mosditchian, G., 1978. Seismic stratigraphy and related lithofacies of the Blake-Bahama Basin. In Benson, W. E., Sheridan, R. E., et al., Init. Repts. DSDP, 44: Washington (U.S. Govt. Printing Office), 529-546.

Sheridan, R. E., Windisch, C. C., Ewing, J. I., and Stoffa, P. L., 1979. Structure and stratigraphy of the Blake Escarpment based on seismic reflection profiles. Am. Assoc. Pet. Geol. Mem., 29: 177-186.

Steiner, M. B., 1980. Investigation of the geomagnetic field polarity during the Jurassic. J. Geophys. Res., 85:3572-3586.

Strangway, D. W., 1970. History of the Earth's Magnetic Field: New York (McGraw-Hill Book Co.).

Tissot, B., Demaison, G., Masson, P., Delteil, J. R., and Combaz, A., 1980. Paleoenvironmental petroleum potential of Middle Cretaceous black shales in Atlantic basins. Am. Assoc. Pet. Geol. Bull., 64:2051-2063.

Todd, R. G., and Mitchum, R. M., Jr., 1977. Seismic stratigraphy and global changes of sea level. Pt. 8: Identification of upper Triassic, Jurassic, and Lower Cretaceous seismic sequences in Gulf of Mexico and offshore West Africa. Am. Assoc. Petrol. Geol. Mem., 26:145-163.

Tucholke, B. E., and Mountain, G. S., 1979. Seismic stratigraphy, lithostratigraphy and paleosedimentation patterns in the North
American Basin. In Talwani, M., Hay, W., and Ryan, W. B. F. (Eds.), Deep Drilling Results in the Atlantic Ocean: Continental Margins and Paleoenvironment. Am. Geophys. Union, Maurice Ewing Series, 3:58-87.

Vail, P. R., Mitchum, R. M., Jr., Shipley, T. H., and Buffler, R. T., 1980. Unconformities of the North Atlantic. Phil. Trans. R. Soc. London, A294:137-155.

Vail, P. R., Mitchum, R. M., Jr., and Thompson, S., 1977. Global cycles of relative changes in sea level. Am. Assoc. Pet. Geol. Mem., 26:83-97.

van Hinte, J. E., 1976a. A Cretaceous time scale. Bull. Am. Assoc. Pet. Geol., 60(4):498-516.

1976b. A Jurassic time scale. Bull. Am. Assoc. Pet. Geol. 60(4):489-497.

Vogt, P. R., and Einwich, A. M., 1979. Magnetic anomalies and seafloor spreading in the western North Atlantic and a revised calibration of the Keathley (M) geomagnetic reversal chronology. In Tucholke, B. E., Vogt, P. R., et al., Init. Repts. DSDP, 43: Washington (U.S. Govt. Printing Office).

von Huene, R., Langseth, M., Nasu, N., and Okada, H., 1982. A summary of Cenozoic tectonic history along the IPOD Japan Trench transect. Geol. Soc. Am. Bull., 93:829-846.

von Rad, U., and Arthur, M. A., 1979. Geodynamic, sedimentary and volcanic evolution of the Cape Bajador continental margin (N.W. Africa). In Talwani, M., Hay, W., and Ryan, W. B. F. (Eds.), Deep Drilling Results in the Atlantic Ocean: Continental Margins and Paleoenvironment. Am. Geophys. Union, Maurice Ewing Series, 3:187-205.

Webb, C., 1981. A radiometric time scale of the Triassic. J. Geol. Soc. Australia, 28:107-121.

Westermann, G. E. G., and Riccardi, A. C., 1976. Middle Jurassic ammonite distribution and the affinities of the Andean faunas. Primer Congr. Geol. Chileno, 1:23-39.

Date of Initial Receipt: November 15, 1982 